\title{
VÝVOJ HISTORICKÉ ZÁSTAVBY PARCELY NĚKDEJŠÍHO DOMU Č. 24 NA KOPEČNÉ ULICI V BRNĚ
}

\author{
ANTONÍN ZŮBEK
}

\begin{abstract}
Abstrakt: Příspěvek shrnuje výsledky záchranného archeologického výzkumu parcely někdejšiho domu č. 24 na Kopečné ulici v Brně, který se realizoval v roce 2012. Na jejich základě a po konfrontaci s archivnimi prameny se podařilo do jisté míry rekonstruovat vývoj a podobu zástavby od druhé poloviny 17. do 60. let 20. století. Parcela byla součástí sidelni struktury brněnských předměstí.
\end{abstract}

Klíčová slova: novověk - Brno-předměstí-zástavba.

\section{Historical Building Development of the Plot of House No. 24 in Kopečná Street, Brno}

Abstract: This article sums up the results of rescue archaeological research into the plot of the former house no. 24 in Kopečná Street, Brno carried out in 2012. Based on these results and upon comparison with archive sources, it was possible to partially trace back the development and form of building on the plot from the second half of the 17th century until the 1960s. The plot was part of the settlement structure of Brno suburbs.

Key words: modern age-Brno - suburb-construction.

\section{Historický úvod}

Kopečná ulice náleží od 60. let 20. století ke katastrálnímu území Staré Brno. Na přechodnou dobu od 40. let ji územní reforma učinila součástí katastru Brno-město. V předcházejícím období patřila ke katastrálnímu celku Velká a Malá Pekařská ulice (Kuča 2000, 476, 477). Malá Pekařská (Kleine Bäckergasse) byl od 18. století původní název ulice. Nynější označení se objevilo až v roce 1867 v německé podobě Berggasse. Český ekvivalent přišel až s rokem 1918 (Flodrová 1997, 119).

Území kolem Kopečné ulice se nachází v bezprostředním sousedství středověkého města. Rozprostírá se při jihozápadním úpatí skalního ostrohu Petrova, na němž stojí jedna z dominant města, kostel sv. Petra a Pavla, a na jižní mírně vyznívající partii svahu, který se táhne od Pekařské ulice a je svým způsobem pokračováním druhého výrazného skalního útvaru (kopce), na jehož vrcholu byl vybudován hrad Špilberk. Úpatí obou vyvýšenin se nachází v takřka ploché rovině inundace Svrateckého náhonu. Ten po celá staletí tvořil výrazný prvek zdejší krajiny. Pravděpodobně šlo o upravený tok vedlejšího ramene řeky Svratky. Dnes je v těchto místech zasypán a jeho průběh se odráží v linii Vodní ulice. Jeho levostranným přítokem zde byl potůček ze studánky pod Petrovem (později zvané Fons salutis).

Území bylo od založení města zapojeno do jeho předměstské struktury. Na severu ho vymezovala Pekařská ulice, původně Velká Pekařská - Grosse Bäckergasse, ve stř̌edověku Peckyngasse či platea Pistorum (Flodrová 1997, 178). Šlo o komunikaci, která spojovala město od vyústění z Brněnské brány s osídlením na Starém Brně. To ve středověku představovalo obtížně zařaditelný útvar s vlastním rychtářem a blížilo se postavení městečka (Flodrová-Müller 2007; Kuča 2000, 518-535; Procházka-Kolařík-Zůbek 2013, 558-568). Na jeho východním obvodu při dolní (západní části) Pekařské ulice byla vybudována komenda johanitského řádu s př́islušným zázemím. Východně od ní při jižní linii Pekařské ulice byl v roce 1312 založen Janem Lucemburským a Eliškou Přemyslovnou klášter dominikánek při kostele sv. Anny.

Ve stř̌ední části probíhala Pekařská ulice ze severní strany kolem osídlení na Provaznickém vršku (Lochenberg - dnes přibližně Kopečná 43), které bylo označováno jako Statek kostela Všech svatých. Lidé sídlící kolem kostela (v roce 1387 celkem 22 poplatníků) nebyli z hlediska právního postavení typickými představiteli předměstí, ale ani klasickými poddanými cizí vrchnosti, město zde nepochybně uplatňovalo svoji soudní svrchovanost a alespoň v některých letech vybíralo městskou sbírku (Procházka-Kolařík-Zůbek 2013, 568). Byl vysloven názor, že 


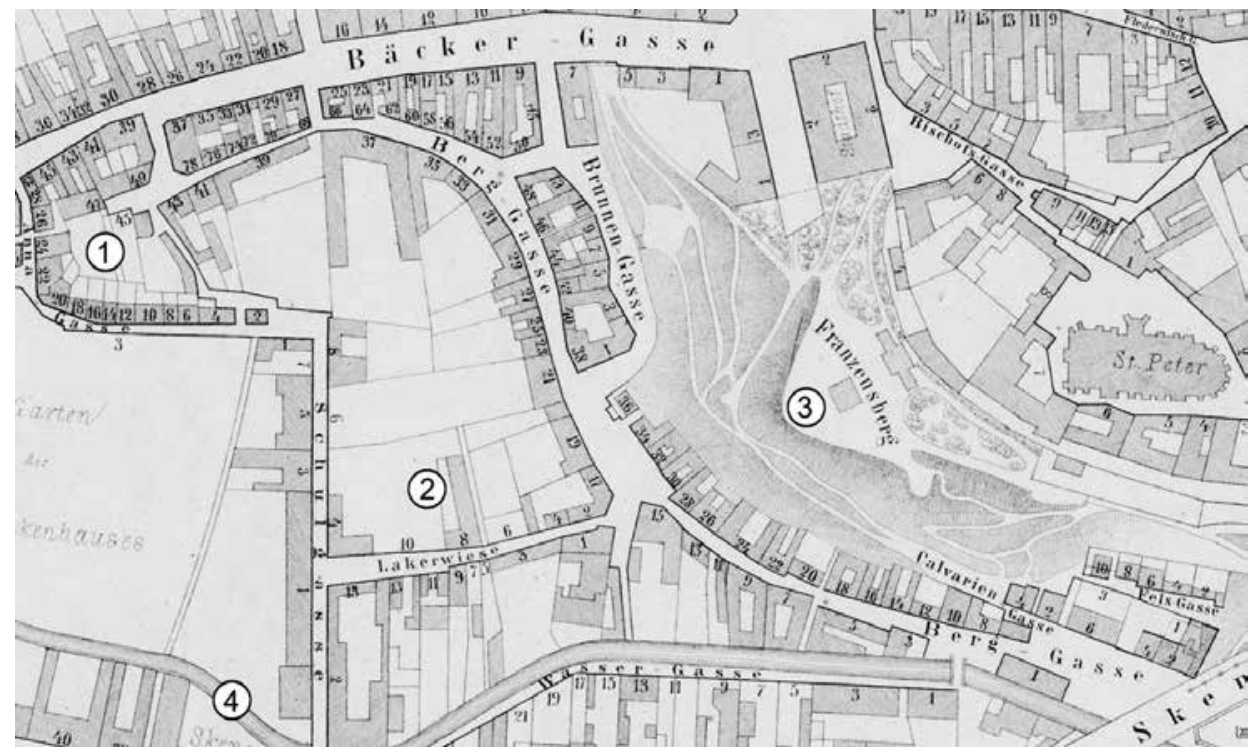

Obr. 1. Výřez plánu z roku 1868 s územím kolem Kopečné ulice. Domy označeny orientačními čísly, zavedenými v roce 1867, Archiv města Brna, fond U 9, sign. K37a. Čísla v bílých kroužcích označují polohu v textu zmiňovaných míst: 1 - Provaznický vršek, 2 - zamokřený terén městské louky (Žabí louže, Lackerwiese), 3 - Puhlík, 4 -Svratecký náhon.

Abb. 1. Ausschnitt einer Planskizze aus dem Jahr 1868 mit dem Gebiet um die Straße Kopečná. Die Häuser sind mit den im Jahr 1867 eingeführten Hausnummern gekennzeichnet, Archiv der Stadt Brno, Bestand U 9, Sign. K37a. Die Ziffern in den weißen Kreisen kennzeichnen die Lage der im Text erwähnten Stellen: 1 - Lochenberg, 2 - städtische Feuchtwiese (Lackerwiese), 3 - Purzelbüchel, 4 - Schwarzawa Mühlgraben.

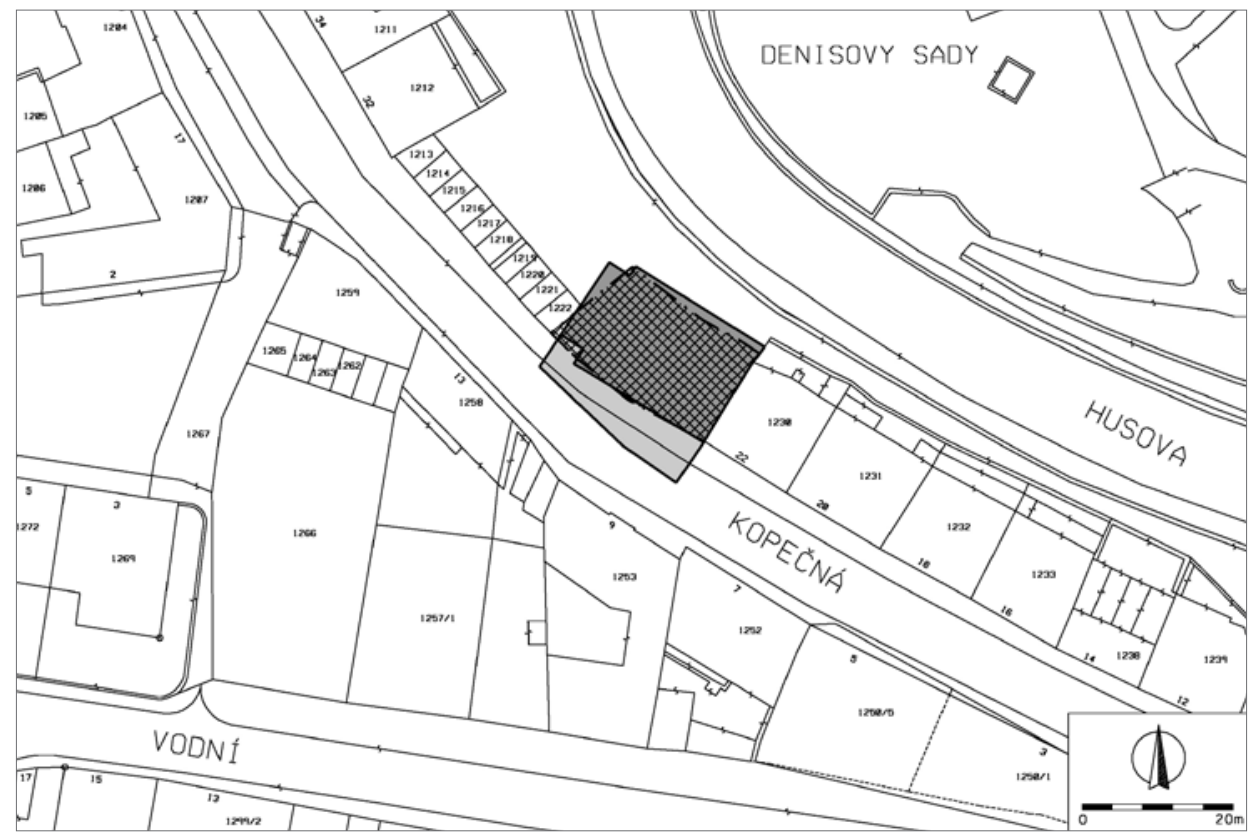

Obr. 2. Poloha zkoumané plochy. Vyznačena šrafurou. Tmavě šedá plocha - parc. č. 1160/30, světle šedá plocha - parc. č. 1160/20.

Abb. 2. Lage der untersuchten Fläche. Schraffiert gekennzeichnet. Dunkelgraue Fläche - Parz. Nr. 1160/30, hellgraue Fläche - Parz. Nr. 1160/20. 
šlo o samostatnou osadu s rychtářem a konšely, jejíž vrchností byl farář u Všech svatých (Dřímal 1973, 264, 265).

V horní (východní) části Pekařské ulice vzniklo osídlení nazývané „před branou Brněnskou“ (ante portam Brunnensem). Zdejší obyvatelé již představovali typické zástupce brněnských předměstí, která náležela městu. Tato předměstí utvářela víceméně souvislý prstenec, který bezprostředně obepínal obvod města vymezený fortifikačním pásem. Rozvíjela se v podstatě souběžně s vnitřním městem již od první poloviny 13. století. Rozdělena byla do čtyř čtvrtí (ke středověké struktuře předměstí stále Vičar 1966, podle něj nověji Procházka-Kolařík-Zůbek 2013, 568-600, základní historický přehled Kuča 2000). Osídlení „před branou Brněnskou“ příslušelo ke čtvrté čtvrti (Quartum quartale extra civitatem).

V berním rejstříku z roku 1348 jsou hned za poplatníky z předměstské části „,před branou Brněnskou“ uvedeni neúplně jako poslední skupina poplatníků „chudí pod Puhlíkem“. Rejstř́ík z roku 1365 uvádí asi 21 domků chudiny, dělníků, nosičů apod. (Procházka-Kolařík-Zůbek 2013, 597; Vičar 1966, 234). Termínem „Puhlík“ se ve středověku rozuměl výběžek Petrova v místě dnešních Denisových sadů (dříve také Františkov). Osada „chudých pod Puhlíkem“ se zřejmě nacházela při Kopečné ulici v jejím úseku severně od vyústění dnešní uličky Studánka, což zdá se potvrzují výsledky dosavadních archeologických výzkumů (Černá a kol. 2013, 167-168; Holub a kol. 2005, 150; Zůbek 2016).

Dnešní Kopečná ulice se vyvinula z někdejší komunikace, která se pod východním úpatím Provaznického vršku odkláněla od Pekařské ulice a směřovala podél úpatí Petrova ke Svrateckému náhonu. Za ním se nacházela ves Novosady, která ležela $\mathrm{v}$ bezprostředním jihozápadním sousedství města. Podél náhonu bylo možné se dostat skrze západní část první předměstské čtvrti k Židovské bráně (dnes ústí Masarykovy ulice), kterou se město otevíralo směrem k jihu.

Zástavba podél komunikace se utvářela postupně. V období středověku byla pravděpodobně osídlena jen oblast kolem severozápadní partie ulice. Šlo o zmíněné osady „chudých pod Puhlíkem“a při kostele Všech svatých. K utváření zástavby podél jihovýchodního úseku cesty docházelo zřejmě až v období novověku. O starším osídlení se písemné prameny nezmiňují a př́ípadnou zástavbu nelze pozorovat ani na nejstarších vyobrazeních. Na obrazu H. B. Beyera a H. J. Zeisera z poloviny 17. století ovšem není zaznamenána ani zástavba v prostoru osady „chudých pod Puhlíkem“ a předměstí „před branou Brněnskou“. Patrný je pouze kostel Všech svatých snad s nezřetelně vyobrazenými přilehlými stavbami. Obraz dokumentující švédské obléhání města $\mathrm{v}$ roce 1645 přitom poměrně přesně a věrohodně zachycuje podobu města a jeho okolí (uložen ve sbírkách Muzea města Brna pod inventárním číslem 2284). Stejnou situaci zaznamenávají další, už méně přesná vyobrazení ze stejné doby - mědirytina Merianova (součást knihy Merian 1650) a anonymní plán ze spisu Relatione dell assedio di Bruna e de la fortezza di Spilberg (v seznamu pramenů pod Relatione). Zástavbu zobrazuje až Folpert van Ouden Allen asi okolo roku 1690 (uloženo ve sbírkách Muzea města Brna). Ovšem věrohodnost a přesnost jeho obrazu je otázkou. Zástavba po obou stranách jihovýchodní partie Kopečné ulice je zakreslena např́íklad na plánech z let 1729 (Österreichisches Staatsarchiv - Kriegsarchiv, Inland C IV a) Brünn Nr. 12, 1729), 1749 (Österreichisches Staatsarchiv - Kriegsarchiv, Inland C IV a) Brünn Nr. 14, 1749) a 1754 (zachován v kopii z roku 1815 - Archiv města Brna, U 9, sign. K 11) a pak samozřejmě na dalších plánech z druhé poloviny 18. a 19. století.

Důvody pro neosídlení daného prostoru v nejstarším období lze přisuzovat nepříznivým prŕrodním podmínkám. Skála Petrova zde spadá přímo do inundace Svrateckého náhonu. Šlo o silně zamokřený terén. Měla se zde údajně nacházet bažinatá městská louka, zvaná (od 15. století) Žabí louže (Lacus ranarum). Později byl prostor označován jako Lackerwiese („loužová louka“ - Kuča 2000, 372, 373). Informace písemných pramenů podpořily poznatky archeologických výzkumů a výsledky prŕírodovědných analýz (k tomu např. Zapletalová a kol. 2005). Bažinatý terén musela obcházet i komunikace (Kopečná ulice), která byla vysunuta co nejvýše při samém úpatí Petrova. U Svrateckého náhonu jsou v prostoru ,pod Puhlíkem“ zmiňovány archivními prameny pouze lázně a mlýn, později zvaný Lamplův (Flodrová-Müller 2007, 192, 193; Procházka-Kolařík-Zůbek 2013, 598). Po roce 1782 začalo být zamokřené území zasypáváno 
navážkami a osidlováno. Vzniklá obec se konstituovala jako samostatné katastrální území Lackerwiese, ve 20. a 30. letech 20. stolení V Jirchářích. Zahrnovalo dnešní ulici Jircháře, severní úsek Leitnerovy a větší část Vodní ulice (Kuča 2000, 372, 373). Západně od něj se nacházelo Území Svaté Anny, které se jako samostatný katastrální celek etablovalo na pozemcích zrušeného kláštera dominikánek (po krátkou dobu v první polovině 20. století U Svaté Anny - Kuča 2000, 571-573). Dnes se víceméně jedná o areál Fakultní nemocnice u sv. Anny. Severně a východně od Jirchářů se rozprostíral katastr Velká a Malá Pekařská ulice, zahrnující rovněž novou zástavbu jihovýchodního úseku dnešní Kopečné ulice.

Pro středověké období lze konstatovat, že velká část předmětného území nebyla kvůli přírodním poměrům sídelně atraktivní. Lidé se usadili pouze v jeho severní partii na úpatí svahů dvou vrcholových dominant kraje (Petrov a Špilberk) s lokálně výrazným prvkem Provaznického vršku. Osídlení zde vzniklo podle archeologických pramenů již v době před založením města (zřejmě v průběhu 12. století). K jeho přesnému charakteru a časovému zařazení se nelze blíže vyjádřit. Příslušné archeologické výzkumy nebyly zatím vyhodnoceny nebo jen dílčím způsobem (stručně k dosavadním výsledkům Procházka-Wihoda-Zapletalová 2011, 538). Důležité informace mohou přinést budoucí archeologické výzkumy při plánovaných stavebních počinech v tomto prostoru. Ve 13. století bylo zdejší osídlení zařazeno do předměstské struktury Brna. Teprve v období novověku dochází k osídlování zbylé části území, která původně těmto aktivitám nevyhovovala.

\section{Historie domu Kopečná 24}

Historii domu stručně zpracoval PhDr. Pavel Borský, CSc. Jeho rukopis je v upravené podobě součástí nálezové zprávy z archeologického výzkumu (Borský 2015). Následující odstavce z této práce ve velké části vycházejí.

Někdejší dům Kopečná 24 byl zbourán na počátku 60. let 20. století. Jeho parcela je ve stávajícím systému katastrálních jednotek rozdělena do dvou základních partií. Většinovou část původního pozemku zabírá parcela č. 1160/30, na které byla postavena novostavba čp. 998/24, menší část, kde stávalo čelo domu, přináleží parcele č. 1160/20. Původní dům Kopečná 24 byl součástí zástavby jihovýchodního úseku ulice. Spoluvytvářel uliční frontu při severní linii komunikace. Jeho pozemek byl usazen mezi veřejnou cestou a hranou skalního ostrohu Petrova. Dům byl při zavedení popisných čísel označen nejprve jako čp. 92, později čp. 84. Po přidání orientačních čísel v roce 1867 byl určen jako číslo 24 .

V adresáři z roku 1785 je jako majitel domu uveden řezník Josef Kellner. S jistou mírou pravděpodobnosti lze uvažovat, že se k jeho pozemku vztahuje zápis z roku 1710 v Sirotčí knize předměstí Velká a Malá Pekařská. Uvádí, že Hannß Ernst Kellner koupil za 12 zlatých od magistrátu na Pekařské na území Všech svatých pusté místo o šířce šest sáhů mezi Janem Mádlem a Petrem Rechauerem (Archiv města Brna, fond A 1/3, rkp. č. 147, fol. 10). V roce 1794 prodal Josef Kellner svůj dům za 850 zlatých Josefu Kuchtíčkovi, kočímu paní von Blümegen. Dovídáme se, že k domu patřila stáj a chlév pro dobytek, který i po prodeji Kellner dočasně užíval (Archiv města Brna, fond A 1/3, rkp. č. 1914, fol. 76). Krátce nato postoupil Kuchtíček dům svému bratru Petrovi, který býval podkoním (Archiv města Brna, fond A 1/3, rkp. č. 1915, fol. 2). V roce 1801 Petr Kuchtíček prodal dům včetně chlévů za 1500 zlatých kočímu Johannu Weissovi (Archiv města Brna, fond A 1/3, rkp. č. 1915, fol. 70).

V roce 1820 ocenili zednický mistr Vavřinec Češka a tesařský mistr Kašpar Tuček dům na 4000 zlatých. Popsali jej jako patrovou rozlehlou stavbu s dvorními kř́ídly, stájemi a dvorem o výměře 28 čtverečních sáhů. $Z$ ulice vedla dvoukřídlá brána do plochostropého průjezdu. Napravo proti ulici byla prostorná vozová kolna, $\mathrm{v}$,postranni budově vpravo od kolny“ klenutá stáj pro pět koní a vedle druhá stáj pro dva koně. Nad druhou stájí se nacházela sýpka s cihelnou dlažbou. $\mathrm{V}$ př́zemí nalevo proti ulici byly dva vytápěné pokoje, za nimi předsín s klenutou kuchyní. Vedle předsíně byla další vytápěná místnost s přilehlou kuchyní. Následovala předsín se schodištěm do patra. Na konci budovy se nacházel vytápěný klenutý pokoj a za ním klenutá 
kuchyně. V prvním patře byly ze strany ulice dvě vytápěné místnosti a předsíň. V předsíni s trámovým stropem byla klenutá kuchyně a vedle ní vytápěný pokoj. Dále popsali celkem tři kuchyně „auf dem Mantel gewölbte“, předsíň a pokoj. Krov a pálená krytina měly být „v nejnovějším stavu“ (Archiv města Brna, fond A 1/3, rkp. č. 1915, fol. 70).

V roce 1825 Johann Weiss s manželkou Kateřinou prodali dům Johannu Friedrichovi Girkemu za 4560 zlatých. Na domě vázly dluhy ve výši 1528 zlatých. Manželé Weissovi doživotně užívali byt v prvním patře „vzadu“ (Archiv města Brna, fond A 1/3, rkp. č. 1917, fol. 160). Johann Friedrich Girke dům v roce 1842 prodal za 7200 zlatých Johannu Christovi s dluhem ve výši 6200 zlatých (Archiv města Brna, fond A 1/3, rkp. č. 1918, fol. 310). V roce 1844 dům získali za 8000 zlatých manželé Karel a Marie Kindlovi (Archiv města Brna, fond A 1/3, rkp. č. 1919, fol. 66). Za stejnou cenu od nich dům koupila v roce 1846 Anna Kretschmerová, vdova po stolaři (Archiv města Brna, fond A 1/3, rkp. č. 1919, fol. 100). Po její smrti v roce 1848 zdědili dům její děti Bernard, Marie, Josefa, provdaná Heiterová, a Anna, provdaná Př́íhodová (Archiv města Brna, fond A 1/3, rkp. č. 1919, fol. 169).

V domě nadále hospodařil Bernard Kretschmer, který byl také stolařem. Dlouho a neúspěšně usiloval o radikální přestavbu domu. V letech 1853, 1862 a 1864 žádal opakovaně o stavební povolení k výstavbě druhého patra. Komise žádost vždy odmítla s poukazem na mělké základy a nedostatečnou tloušt'ku obvodových zdí, která činila 18 palců (Archiv města Brna, fond A 1/33, inv. č. 718, kart. 175). Nepovolena zůstala i adaptace dřevěné patrové kolny ve dvoře na zděných pilířích $\mathrm{v}$ roce 1860 . Schváleny byly jenom drobnější úpravy. V roce 1858 žádal Kretschmer o povolení vybourat okno a zrrídit krám, v roce 1860 o povolení upravit dřevník v přízemí na obytnou místnost. V roce 1877 se předmětem stavebního řízení stal vadný komín (Archiv města Brna, fond A 1/33, inv. č. 718, kart. 175). Po smrti Bernarda Kretschmera vlastnila dům jeho manželka Terezie. V adresáři z roku 1907 je jako majitel uveden syn Franz Kretschmer.

\section{Archeologický výzkum}

Archeologické poznatky o vývoji parcely domu Kopečná 24 byly získány při záchranném archeologickém výzkumu v roce 2012, který byl vyvolán novostavbou „Parkovacího domu Kopečná“. Výzkum realizovala společnost Archaia Brno, o.p. s. (akce č. A53/2012 - Černá-Zůbek 2015). Byl to jediný dokumentovaný archeologický počin, který se na parcele uskutečnil. Zkoumána při něm byla jen část původního pozemku, dnešní parcela č. 1160/30. Partie při původní uliční čáře (parcela č. 1160/20) zůstala „ukryta“ pod veřejným pozemkem komunikace. Dnešní linie Kopečné ulice je v těchto místech upozaděna o 4 až 6,5 m. Exkavovaná plocha měla přibližně obdélný půdorys o výměře $302 \mathrm{~m}^{2}$ (ca $21,5 \times 14 \mathrm{~m}$ ). Rozlohu celého pozemku lze podle archivních pramenů a s přihlédnutím $\mathrm{k}$ archeologickým poznatkům stanovit na $420 \mathrm{~m}^{2}$ (ca 21,5 × 19m). Archeologický výzkum tudíž probíhal na $72 \%$ z celkové výměry původní parcely.

Vlastnímu archeologickému výzkumu na ploše staveniště předcházely zjištovací sondy, které měly ověřit terénní podmínky lokality. Jedna byla položena v jihozápadním rohu, druhá ve střední části. Na základě jejich zjištění bylo přistoupeno ke snížení recentních navážek prostřednictvím mechanizace. Bezprostředně navazoval archeologický výzkum. Byl proveden metodou plošné exkavace veškerých archeologických situací až na úroveň geologického podloží. Výzkum byl realizován před zahájením stavebních prací. Všechny odkryté archeologické situace byly při nich zničeny. Zůstala zachována jen spodní část objektu s. s. j. 001.

Geologické podloží tvoři skála. Jde o zelenavě zbarvené metabazalty (paleočediče), ze kterých je složena metabazitová zóna brněnského masivu prekambrického stáří reprezentující Český masiv. Antropogenní část terénu sestávala z dílčích stratigrafických jednotek (s. j.), které bylo možné rozdělit do tří základních skupin. Nejméně početnou byly výkopy (8), následovaly zděné stavební konstrukce (78) a nejpočetněji byly zastoupeny uloženiny, tj. výplně výkopů a vrstvy (130). Související aktivity byly při zpracování sdruženy do 25 vyšších celků - svazků stratigrafických jednotek (s. s. j.). Četnost zkoumaných jednotek se zvyšovala směrem k někdejší uliční čáře. Při jihozápadní hranici zkoumané plochy dosahovalo archeologické souvrství 


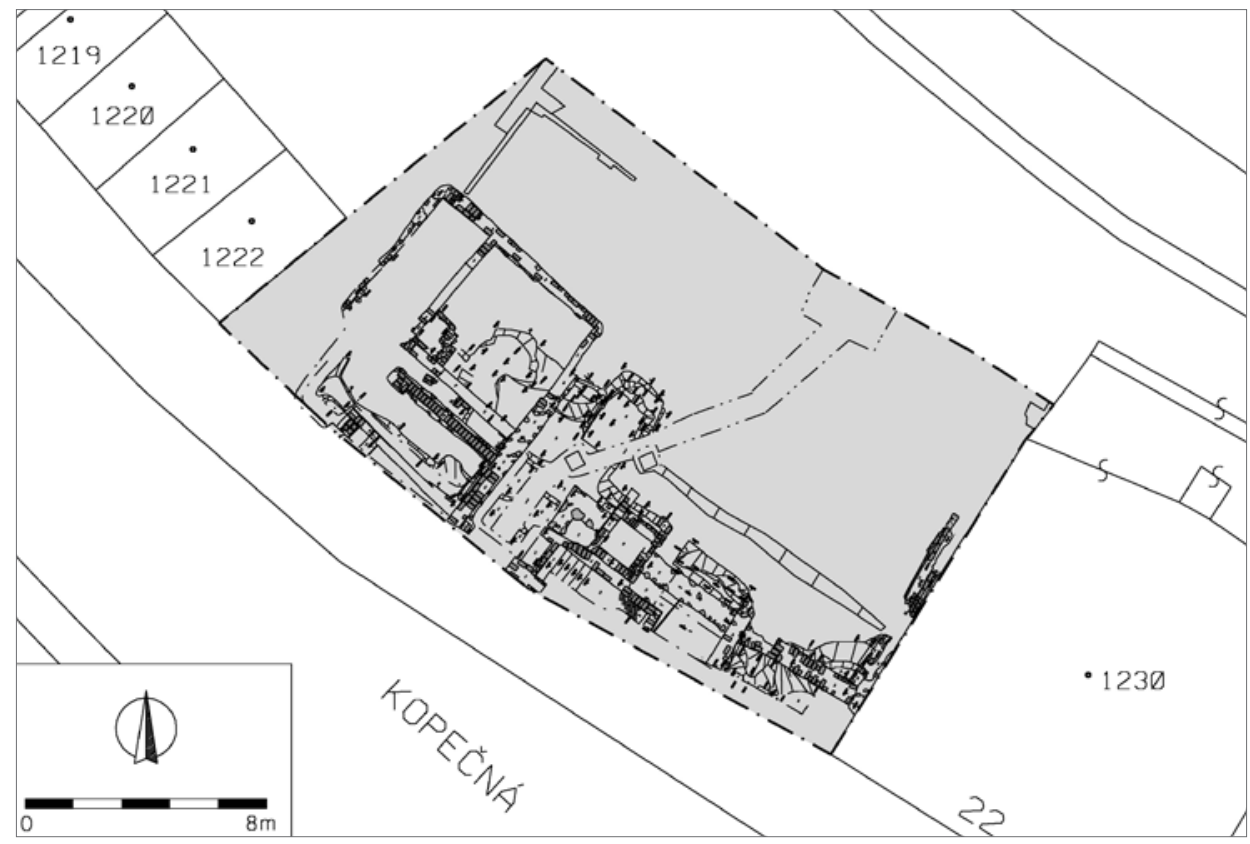

Obr. 3. Zkoumaná plocha v úrovni dokončené exkavace.

Abb. 3. Untersuchte Fläche in Höhe der beendeten Aushebung.

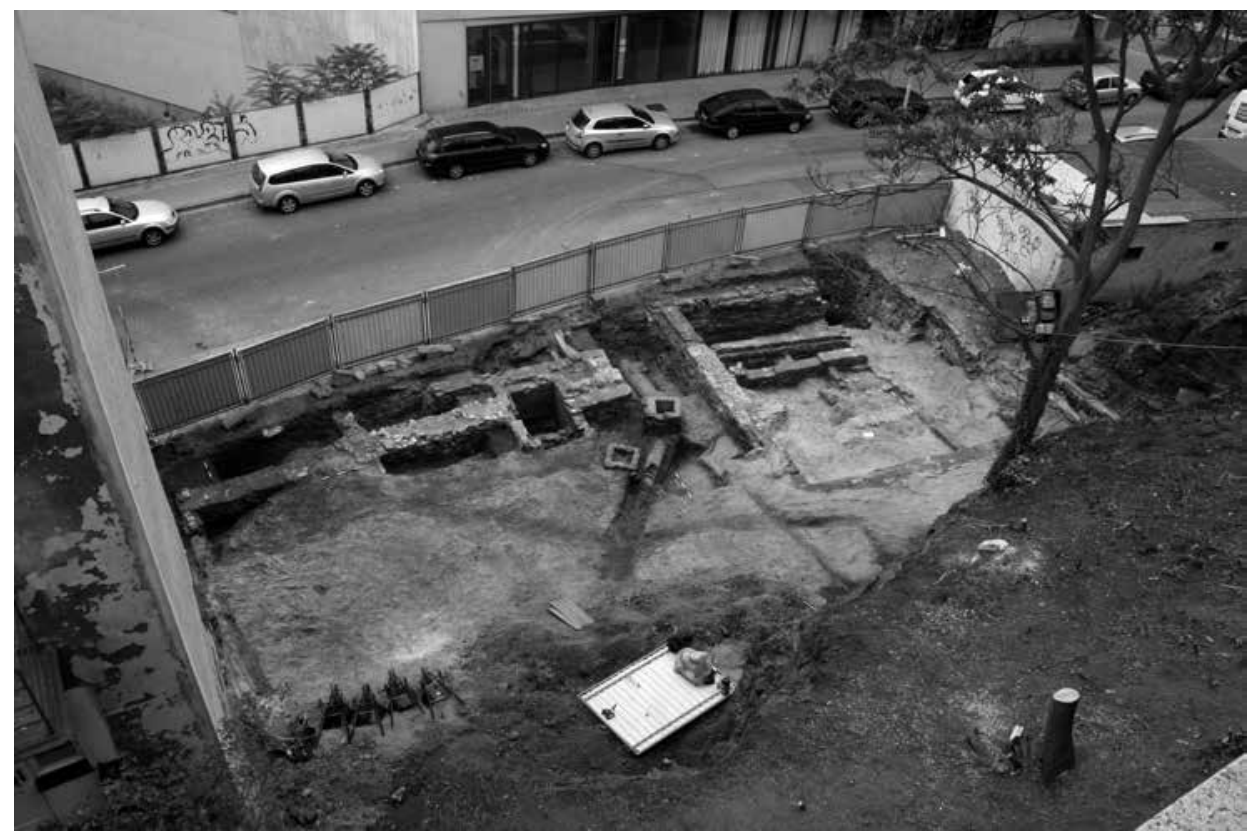

Obr. 4. Pohled od severovýchodu na zkoumanou plochu v úrovni dokončené exkavace. Fotoarchiv Archaia Brno, o. p. s. foto č. 21687-2013.

Abb. 4. Blick von Nordsosten auf die untersuchte Fläche in Höhe der beendeten Aushebung. Fotoarchiv Archaia Brno, o. p. s. - Foto Nr. 21687-2013. 


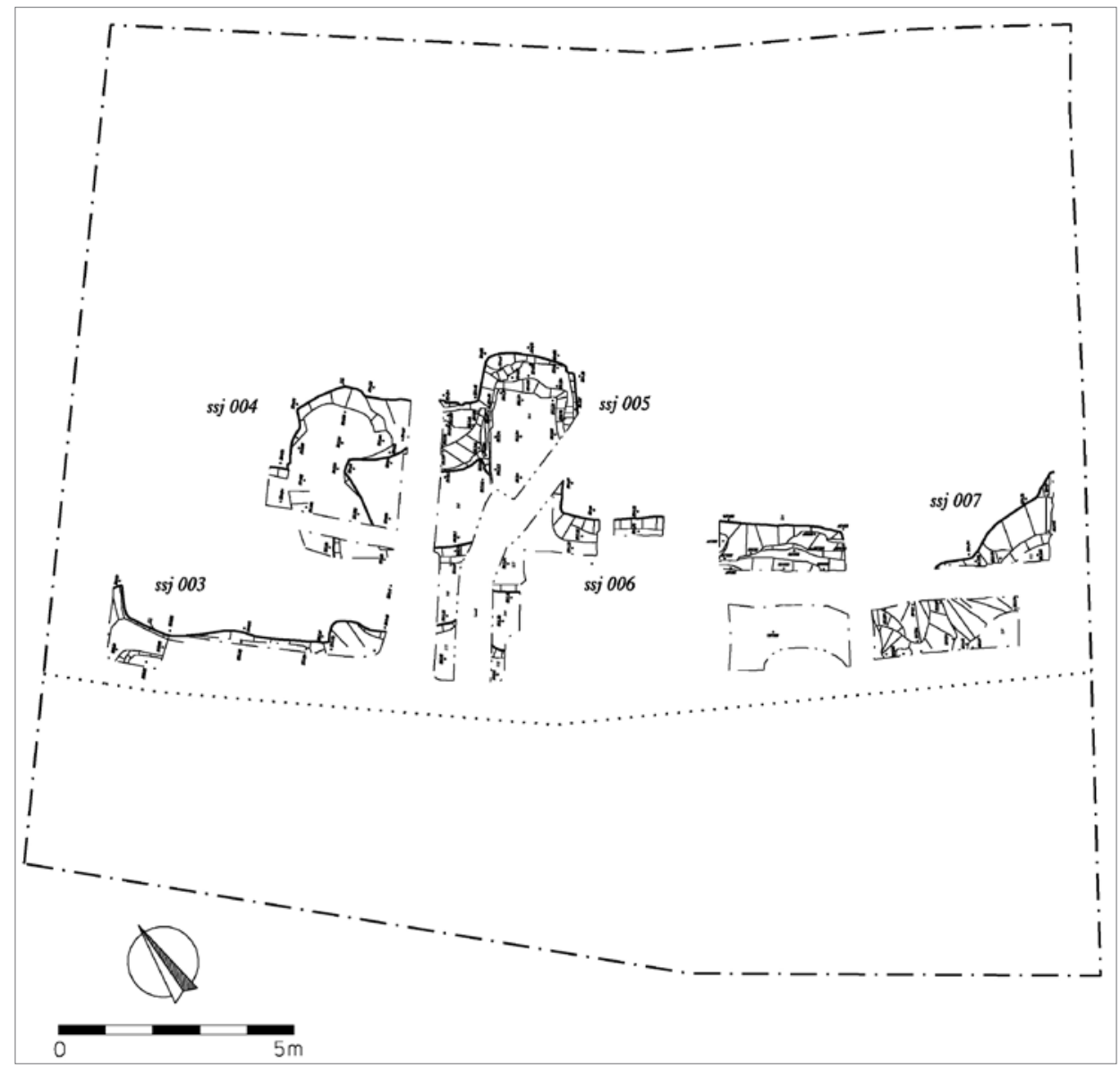

Obr. 5. Nejstarší výkopové aktivity do skalního podloží.

Abb. 5. Älteste Aushubaktivitäten im Felsenuntergrund.

mocnosti $2,50 \mathrm{~m}$. V zadní části parcely byly archeologické terény poněkud jednodušší. Šlo často pouze o relikty zdí usazených přímo na skalní podloží. Drtivá většina zaznamenaných aktivit souvisela se zástavbou. Zděné konstrukce náležely převážně k někdejším budovám, vrstvy často představovaly jejich planýrky, komunikační úrovně nebo terénní úpravy.

V určitých místech byla stratigrafická skladba archeologického terénu natolik složitá, že vyžadovala velice opatrný a odborně vedený postup exkavace. V jihozápadní části staveniště se například podařilo vyčlenit nejméně šest počinů ve stavebním vývoji zástavby. Terénní situace byla roztř́ištěna do několika solitérních celků, nebylo tudíž možné vytvořit celkovou stratigrafickou matici, která by odrážela relativní chronologii všech dokumentovaných aktivit. Datování situací bylo provedeno na základě mobiliáře odebraného z jednotlivých uloženin. Dílčí soubory byly většinou málo početné. Přesnější časové zařazení jednotlivých situací nebylo na jejich podkladě možné. Řada kolekcí obsahovala ,promíchaný“ materiál různého stáŕí. Je to odraz četnosti a intenzity dějů v poměrně krátké době na nevelikém kontinuálně užívaném prostoru.

Archeologickým výzkumem byl získán nálezový soubor čítající na 4800 položek z období novověku (u nejstarších jedinců snad 16., popř́ípadě 17. století) až 20. století. Největší podíl tvoří zlomky keramických nádob. Dále jsou zastoupeny zvířecí kosti, zlomky skleněných nádob 
a železných předmětů (většinou hřebíky či přesněji neidentifikovatelné fragmenty) a předměty z barevných kovů (knoflíky, špendlíky, ozdobná nášivka, spínací očko). Součástí kolekce jsou dvě mince, medailonek a tři fragmenty dýmek, dvou porcelánových a jedné keramické, tvarů obvyklých pro 19.-20. století.

Jednou z mincí je desetihaléř z let 1940-1944, zástupce naprosto běžně nalézaných recentních ražeb. Ve druhém př́ípadě jde o stříbrnou grešli z roku 1680. Byla vyražena ve slezském knížectví Württemberg-Olešnice za vlády Christiana Ulricha (1664-1704). Na českém i moravském území patří olešnické grešle $\mathrm{k}$ běžným jednotlivým nálezovým mincím a také se velmi často vyskytují jako více či méně početná složka dobových hromadných nálezů mincí s převažujícím zastoupením drobného oběživa. Z brněnského prostoru jsou prozatím známy dva případy (Královo Pole - ročník 1704, areál kláštera u sv. Anny - ročník 1696; Smíšek 2014).

V prŕípadě medailonku jde o oválnou svátostku. Na jejím líci je patrná postava se svatozáŕí, oděná v sutaně, která v pravé ruce drží hůl, na jejímž vrcholu je kř́iž. Kolem postavy je nápis CRUX S. P. BENEDICTI. Na rubu je ve středovém poli umístěn křŕž svatého Benedikta; opis mezi rameny C S P B, na vodorovném břevnu NDSMD, na svislém jsou patrná písmena CSSML. Opis kolem kříže lze rekonstruovat jako VRS.N.S.M V.S.M.Q.LIVB IHS. Svátostky tohoto typu jsou označovány jako „Benediktovy feniky“. Měly ochrannou funkci. Jejich nálezy pocházejí prakticky z celého území katolické Evropy. Jednotlivé exempláře se blíže špatně datují. Jejich typologii podal G. M. Lechner (1980, 46-53), který počátky jejich výroby klade do roku 1674.

\section{Nálezová situace}

Nejstaršími antropogenními situacemi jsou výkopové aktivity do skalního podloží (s. s. j. 003 až 007). Jejich přesný účel se nepodařilo objasnit. V případě s. s. j. 007 není vyloučeno, že by mohlo jít pouze o přirozený sklon podloží. Je možné uvažovat o úpravách terénu pro založení

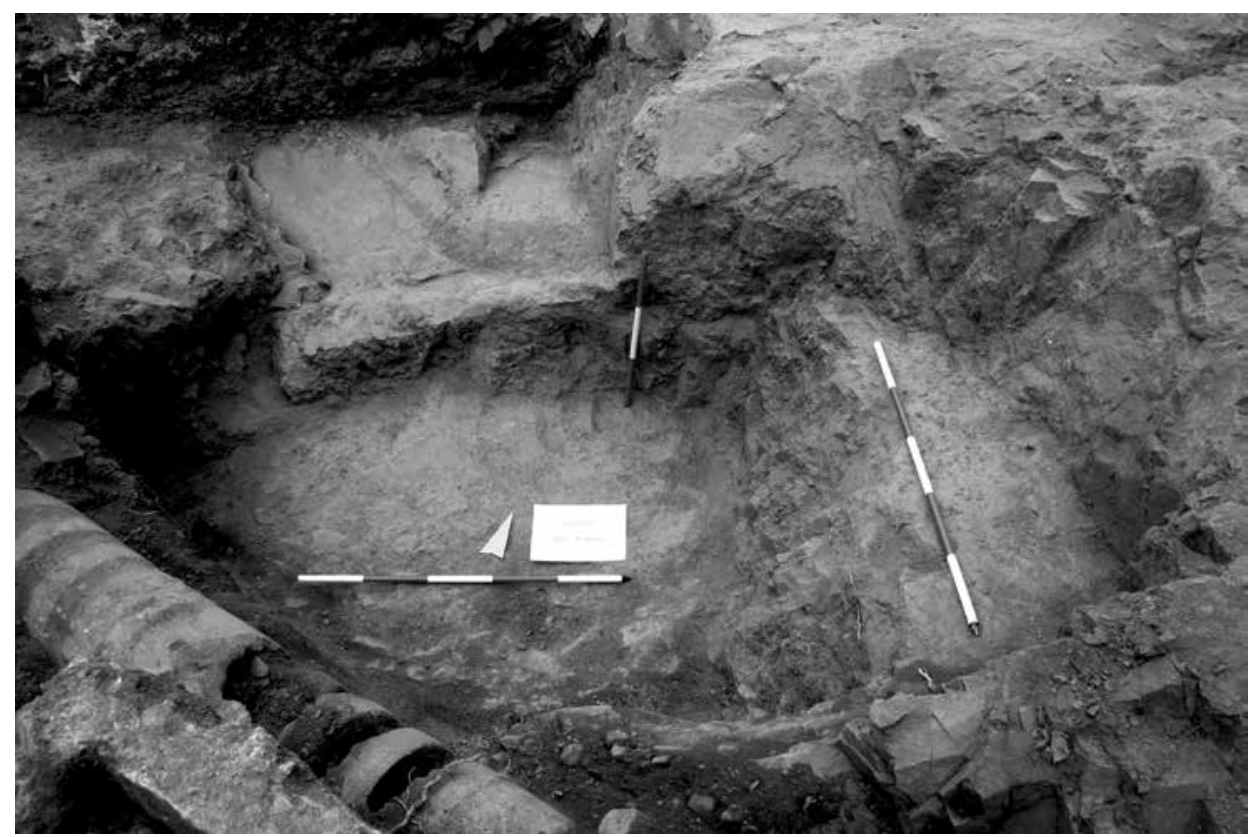

Obr. 6. Sklípek (?) s. s. j. 005 - pohled od jihovýchodu. Fotoarchiv Archaia Brno, o. p. s. - foto č. $21835-2013$.

Abb. 6. Kleiner Kellerraum (?), Bündel stratigraphischer Einheiten 005 - Blick von Südosten. Fotoarchiv Archaia Brno, o. p. s. - Foto Nr. 21835-2013. 
staveb či jejich suterénních partií. Jako sklípek se jevila především situace s. s. j. 005 a severní úsek s. s. j. 003. Hlavní část s. s. j. 005 tvořil přibližně obdélný výkop. Do svažitého skalního podloží byl zahlouben minimálně $0,7 \mathrm{~m}$. Maximální hloubka při severní stupňovité stěně činila $1,5 \mathrm{~m}$. Prostor v úrovni plochého dna měl rozměry $1,3 \times$ ca $2,3 \mathrm{~m}$.

Jednoznačně prokázat hypotézu, že by v př́padě alespoň některých uvedených výkopů mohlo jít o sklepy, nebylo možné. V úvahu připadá varianta, že šlo o pozůstatky těžby kamene. Ten ovšem mohl být druhotně nebo po jistých úpravách k založení staveb využit. Přesné datování těchto aktivit získané poznatky neumožňují. V jejich zásypech se nacházely zlomky keramických nádob, které je možné přisoudit období 16.-17. století. V materiálu výplní převažoval hrubý písek a kamenitý štěrk (z metabazaltů). Dokumentované situace nasvědčovaly interpretaci o jednorázovém zasypání výkopů a účelovém vyrovnání terénu.

Pouze objekt s. s. j. 005 byl zasypán ve dvou fázích. Po zaplnění spodní části zde probíhaly aktivity, jejichž výsledkem byla nejprve situace s. s. j. 019 a poté pyrotechnologické zařízení s. s. j. 020. Vedle toho s. s. j. 019 byla tvořena uloženinou, která vyplňovala mělký výkop (max. $0,25 \mathrm{~m}$ ). Do jisté míry měla charakter destrukce dřevohliněné konstrukce. Na jejím povrchu byla zaznamenána popelová vrstvička o síle $2 \mathrm{~cm}$. Dokumentovaná situace naznačovala dvě fáze $\mathrm{v}$ existenci objektu. Nelze ho označit za přímý pozůstatek otopného zařízení, s provozem využívajícím oheň ale zřejmě souvisel. $Z$ objektu s. s. j. 020 se zachoval relikt jeho cihlové konstrukce. Ta byla postavena na půdoryse $1,3 \times 1,3 \mathrm{~m}$. Zařízení (pec?) mělo dva prostory, oddělené přičkou. Není vyloučeno více fází v budování konstrukce. Nezachovaly se žádné uloženiny související s provozem zařízení. Po jeho ukončení byla konstrukce destruována a došlo k zasypání objektu s. s. j. 005 až po jeho horní hranu.

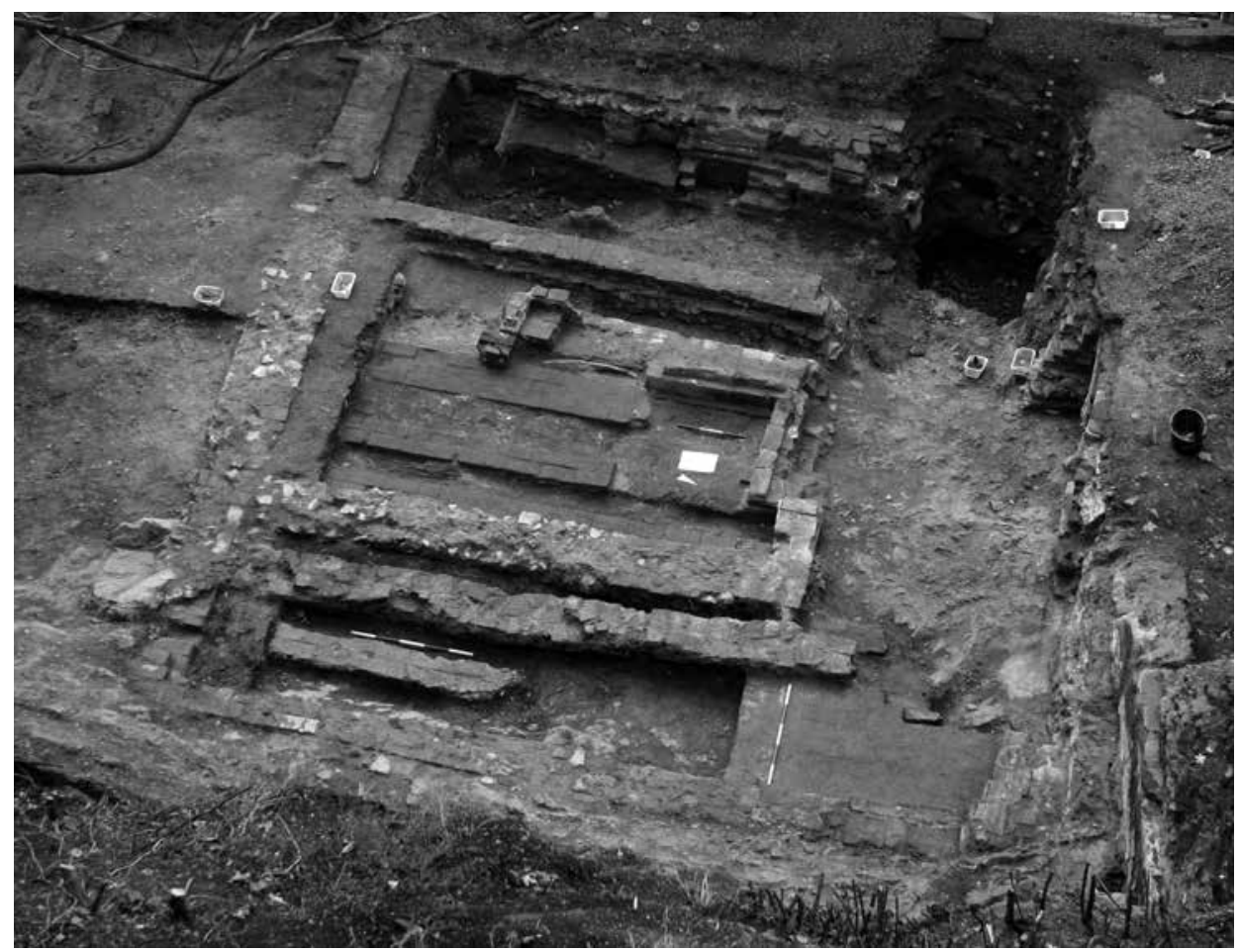

Obr. 7. Dům s. s. j. 013 až 016 - pohled od severovýchodu. Fotoarchiv Archaia Brno, o. p. s. - foto č. 18960-2013.

Abb. 7. Haus, Bündel stratigraphischer Einheiten 013 bis 016 - Blick von Nordosten. Fotoarchiv Archaia Brno, o. p. s. - Foto Nr. 18960-2013. 


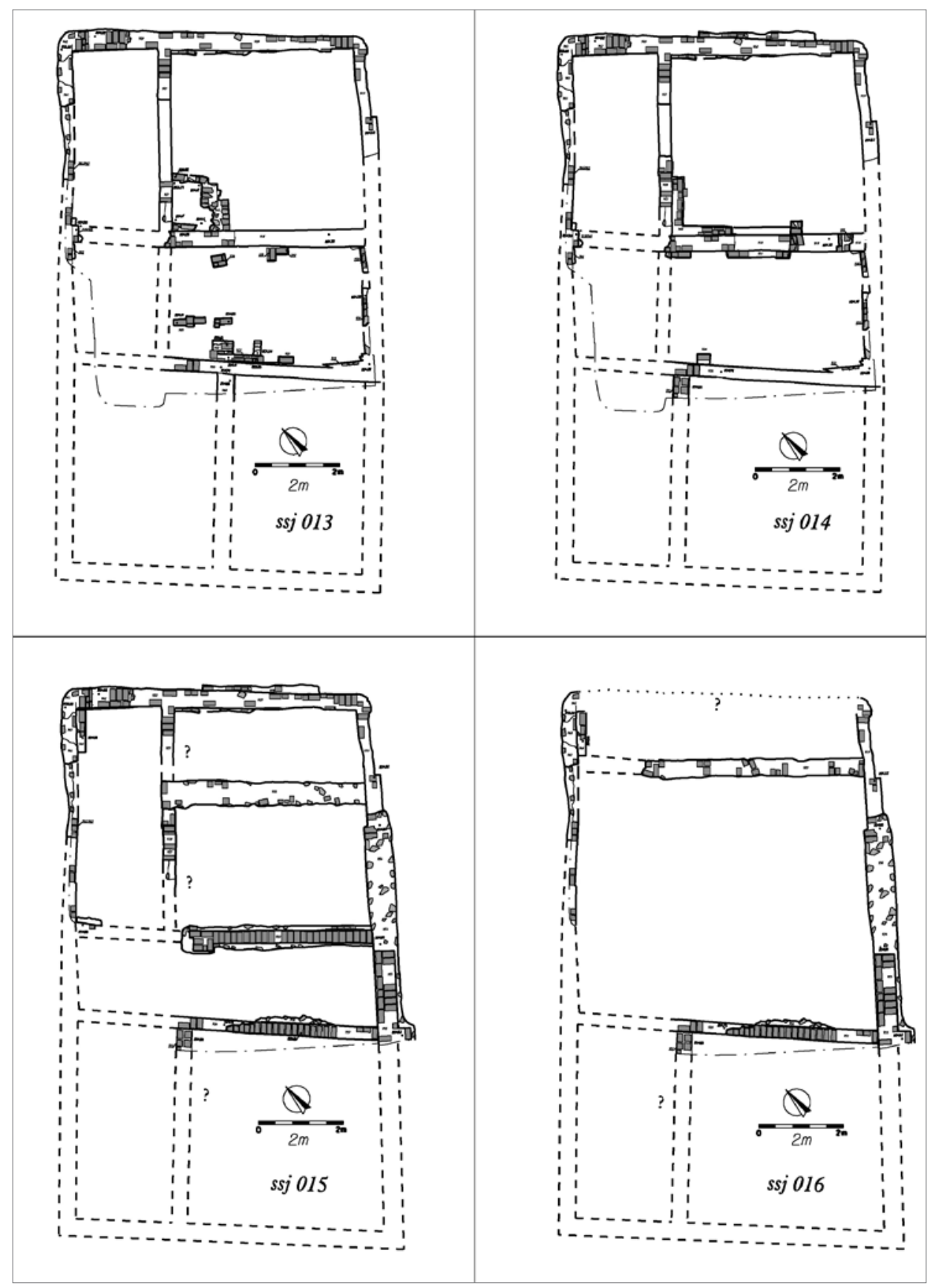

Obr. 8. Dokumentované stavební fáze domu s. s. j. 013 až 016.

Abb. 8. Dokumentierte Bauphasen des Hauses, Bündel stratigraphischer Einheiten 013 bis 016. 
Důvodem zasypání výkopových aktivit do skalního podloží bylo zřejmě budování staveb. Jejich stratigraficky nejstarší pozůstatky byly zachyceny v jihozápadní části zkoumané plochy. Při jejich dokumentaci a analýze bylo dle metodických postupů nutné vyčlenit čtyři svazky stratigrafických jednotek. Situaci lze však interpretovat tak, že šlo o dvě po sobě následující stavby s členěným interiérem (s. s. j. $010+011$ a s. s. j. $008+012$ ). Mladší asi bezprostředně nahradila svou předchůdkyni. Přesný půdorys a charakter staveb nebylo možné ze zachovalých segmentů jednoznačně rekonstruovat. Pravděpodobně šlo o domy stojící při uliční čáře. Zasahovaly minimálně $10 \mathrm{~m}$ do hloubky parcely, jejich šířku lze stanovit na $7 \mathrm{~m}$. Dokumentovaná situace poukazovala na dřevohliněné konstrukce, minimálně na jejich výrazný podíl u obou staveb. Podobné aktivity nebyly zaznamenány již v žádné části zkoumané plochy. Z př́islušných uloženin byl získán keramický materiál datovatelný do 17. století.

Nástupcem jmenovaných staveb v jihozápadní části staveniště se stal dům, při jehož budování se podle dokumentovaných reliktů již výrazně uplatnily na maltu zděné konstrukce. Na základě dokumentované situace bylo v jeho vývoji možné vyčlenit čtyři základní stavební fáze (viz s. s. j. 013 až 016). Půdorys lze rekonstruovat jako přibližně obdélný o šířce $7 \mathrm{~m}$ a délce $12,5 \mathrm{~m}$. Za ním byla registrována stavba s. s. j. 017 s mladší stavební fází (úpravou) s. s. j. 018, která na dům bezprostředně navazovala a byla opřena o skalní stěnu. Není vyloučeno, že mohla mít své předchůdce. Je otázkou, zda lze tuto ,přístavbu“ spojovat již s nejstaršími fázemi domu. Velice pravděpodobné je to pro fáze s. s. j. 015 a 016 . Celková délka budovy by činila $18 \mathrm{~m}$.

Relikty staveb se základy zděnými na maltu byly registrovány také ve východní partii zkoumané plochy. Zřejmě ze stejné doby jako popsaný dům v západní části (snad především fáze s. s. j. 013 a 014) pocházela budova s. s. j. 023. Byla široká $5 \mathrm{~m}$, a pokud její čelo dosahovalo uliční čáry, byla dlouhá minimálně $15 \mathrm{~m}$. Jejím nástupcem se stal dům s. s. j. 024, rozš́řrený při ulici ve směru k sousednímu domu s. s. j. 013-016. Rozš́řrení činilo $6,8 \mathrm{~m}$, do hloubky parcely zasahovala tato př́stavba $8,5 \mathrm{~m}$. Vzniku domu s. s. j. 024 předcházela jáma na hašení vápna s. s. j. 002 $(1,9 \times>1,4 \mathrm{~m}$, hloubka 1,3 m), narušená jámou neznámé funkce s. s. j. 021 (jen segment, snad oválná či kruhová, hloubka 0,9 m). Jáma na hašení vápna mohla druhotně využít jiné zahloubené aktivity s výdřevou stěn. Dům byl při ulici (zřejmě dodatečně) vybaven sklepem s. s. j. 022. Dvorní kř́ídlo domu bylo protaženo až k zadní hranici parcely, ke skalní stěně (stavba s. s. j. 025).

Průběh severní stěny stavby s. s. j. 024 přerušoval objekt s. s. j. 001. Jeho přesný vztah ke stavbě se nepodařilo určit. Mohl mít starší původ, ale do stavby byl zakomponován, nebo byl vybudován současně s ní, popř́ípadě ji doplnil v mladším období. Objekt byl utvořen výkopem do skalního podloží. Měl přibližně oválný půdorys $(1,8 \times 1,6 \mathrm{~m})$ a jeho hloubka přesahovala $2 \mathrm{~m}$. Spodní část, které se nedotkly zemní práce stavby, nebyla zkoumána. V horní partii byl objekt vybaven zděnými cihlovými konstrukcemi tvořícími čtverec o vnitřní světlosti $1,2 \times 1,2 \mathrm{~m}$. Nabízejí se minimálně tři varianty jeho interpretace: 1) zásobník vody, 2) odpadní jímka, 3) skladovací prostor (chladírna). Jako nejpravděpodobnější se jeví poslední možnost. Mohl do jisté míry nahrazovat skladovací funkci sklepa, než byl tento vybudován. Vzájemný časový vztah mezi nimi ale nebyl přesně určen. Není vyloučeno, že objekt s. s. j. 001 byl zasypán ještě před demolicí domu. Ze sklepa s. s. j. 022 byl odhalen jen segment zaklenutého vstupního schodiště, které ústilo do průjezdu domu.

Průjezd domu mezi stavbami s. s. j. 013 až 016 a s. s. j. 024 byl široký 2,2 m. Bylo zde dokumentováno souvrství, které při hranici zkoumané plochy dosahovalo mocnosti $1,3 \mathrm{~m}$. Sestávalo převážně z uloženin, které bylo možné interpretovat jako terénní úpravy a komunikační vrstvy. Některé představovaly asi planýrky dřevohliněných konstrukcí.

Archeologický materiál odebraný z uloženin, které souvisely se zástavbou reprezentovanou zděnými konstrukcemi, lze zařadit většinou do období 17.-18. století (včetně popsané mince z roku 1680 a benediktinské svátostky - viz oddíl 3 Archeologický výzkum). Mladší stratigrafické jednotky obsahovaly též materiál 19.-20. století. Přesnější datování jednotlivých staveb nebylo možné. Snad pouze u vzniku stavební fáze s. s. j. 016 lze s větší jistotou uvažovat nejdříve o 19. století. 


\section{Shrnutí}

\section{Počátky osídlení}

Z poznatků archeologického výzkumu vyplynulo, že nejstarší části zástavby parcely je nutno hledat při původní uliční čáře. Bez výzkumu př́slušné plochy nelze zcela vyloučit možnost středověkého stáří prrípadných staveb. Možná existence jednoduchých obydlí chudiny se nemusela projevit $\mathrm{v}$ záznamu písemných pramenů, ani na prvních ikonografických vyobrazeních prostoru z počátku novověku. Mohlo dojít také ke kratšímu či delšímu přerušení kontinuity osídlení místa. Krátkodobá starší zástavba mohla dojít úplného zapomnění. Jako vysoce pravděpodobná se přesto jeví hypotéza, že k zastavění pozemku a celého př́slušného úseku ulice došlo až v období novověku. I tak bude úkolem příštích výzkumů pokusit se o zodpovězení otázky, zda území nemohlo být dříve využito k jiným než sídelním aktivitám (např. výrobní provozy, těžba kamene).

Počátky zástavby parcely domu Kopečná 24 je možné podle archeologických pramenů usadit do 17. století. Datování vychází především ze získaného nálezového materiálu, jehož hodnota může být v tomto směru problematická (viz oddíl 3 Archeologický výzkum). Je ovšem na zvážení, zda je tu nutná naprostá nedůvěra, zvláště při konfrontaci s výpovědí archivních pramenů. Ta se zdá na první pohled rozporující a počátky osídlení by na jejím základě bylo možné klást nejdříve do počátku 18. století.

Plán z roku 1699 (Österreichisches Staatsarchiv - Kriegsarchiv, Inland C IV a) Brünn Nr. 11, 1699) v těchto místech žádnou zástavbu nezachycuje, zastavěn je pouze prostor severozápadní části Kopečné ulice. V jihovýchodní partii je vyobrazeno opevnění, jehož výstavba však nebyla realizována. Autor plánu mohl zaznamenat jen budoucí projektovanou skutečnost, a príípadnou zástavbu tohoto území pominout.

Hypotézu, že vznik osídlení jihovýchodního úseku Kopečné ulice je nutné spojovat až s počátkem 18. století, může do jisté míry podporovat výpověd' zápisu z roku 1710 (viz oddíl 2 Historie domu Kopečná 24). Z něho se dovídáme, že Hannß Ernst Kellner koupil od magistrátu pusté místo mezi Janem Mádlem a Petrem Rechauerem. Je ovšem otázkou, zda pod výrazem pusté místo máme rozumět ladem ležící pozemek, anebo $\mathrm{v}$ té době nevyužitou, ale původně obývanou parcelu. Stejně tak není jisté, zda Mádl a Rechauer drželi parcely se starší zástavbou, nebo si (krátce předtím) zakoupili pozemky rovněž na pusté půdě (at' už ležící ladem, či na původních parcelách). Skutečnost, že bylo pusté místo koupeno od magistrátu, by hovořila spíše pro ladem ležící obecní pozemek. Opět však nelze zcela vyloučit variantu, že mohlo jít o pustou parcelu, která byla dříve pouze pronajímána či vešla v majetek města například koupí či odúmrtí. Anebo v době prodeje opravdu šlo o ladem ležící pozemek, na kterém ale v minulosti osídlení existovalo.

V případě pozemku domu Kopečná 24 se nabízí hypotéza, že se původně jednalo o dvě parcely (viz dále oddíl Vývoj zástavby). Západní byla v roce 1710 již obydlena, východní, kterou koupil H. E. Kellner, byla pustá. Je otázkou, jaké stáří měla přítomná zástavba. Není tedy nutné vylučovat možnost, že dle archeologického materiálu pocházela minimálně z druhé poloviny 17. století. Náznaky možného osídlení v první polovině tohoto věku, případně již v 16. století, budou muset být do budoucnosti potvrzeny pádnějšími důkazy.

Jako nejpravděpodobnější lze přijmout úvahu, že nová zástavba podél jihovýchodního úseku Kopečné ulice vznikla po třicetileté válce. Válečné události se nepříznivě projevily v životě brněnských předměstí. Naprostou katastrofu představovalo dvojí švédské obléhání v letech 1643 a 1645 a následná přeměna Brna na barokní pevnost. Již před prvním z uvedených obléhání dalo samo město vypálit a strhnout budovy, které by ztěžovaly přehled obránců a umožňovaly Švédům snazší a krytý přístup $\mathrm{k}$ hradbám. Ještě citelnější byly př́ípravy na druhé švédské obléhání roku 1645. Vlastní vojenské akce toto katastrofální postižení předměstí dovršily. Některé části předměstského osídlení zanikly definitivně, struktura jiných se výrazně změnila (Kuča 2000, 67, $79,80)$. Lákavá je v tomto směru myšlenka, zda nemohla být do jihovýchodního úseku Kopečné ulice umístěna skupina př́ípadných „vysídlencü“ z jiných předměstských čtvrtí, jejichž pozemky 
zabralo nové bastionové opevnění města, budované od 60. let 17. století. Této problematice nebyla dosud v historickém bádání věnována výraznější pozornost. Je možné, že úbytek obyvatel v důsledku válečných událostí byl tak výrazný, že nebylo nutné nikoho přesídlovat. Nové osídlení při Kopečné ulici by pak bylo spíše výsledkem obnoveného populačního růstu (k úbytku obyvatel např. Burian 1969, 157, 160).

\section{Vývoj zástavby}

V nejstarším období byla prokazatelně zastavěna jihozápadní část parcely. Při hranici pozemku stál dům štítově orientovaný k uliční čáře. V první fázi se jednalo o dřevohliněnou stavbu (s. s. j. $010+011$ ), při budování druhé fáze byly užity také zděné konstrukce (s. s. j. $008+012$ ). Zástavba obdobného charakteru nebyla nikde jinde na parcele zaregistrována. To ovšem neznamená, že neexistovala. Mohla být beze zbytku odstraněna. Př́ípadné stavby dřevěné konstrukce by na skalním podloží nezanechaly stopy takřka žádné. Terénní situace nedovolila vyřešit otázku, zda pyrotechnologické zařízení s. s. j. 020 mohlo být s touto zástavbou současné, nebo představovalo zástupce starších aktivit. Nacházelo se v blízkosti východní stěny jmenovaných domů

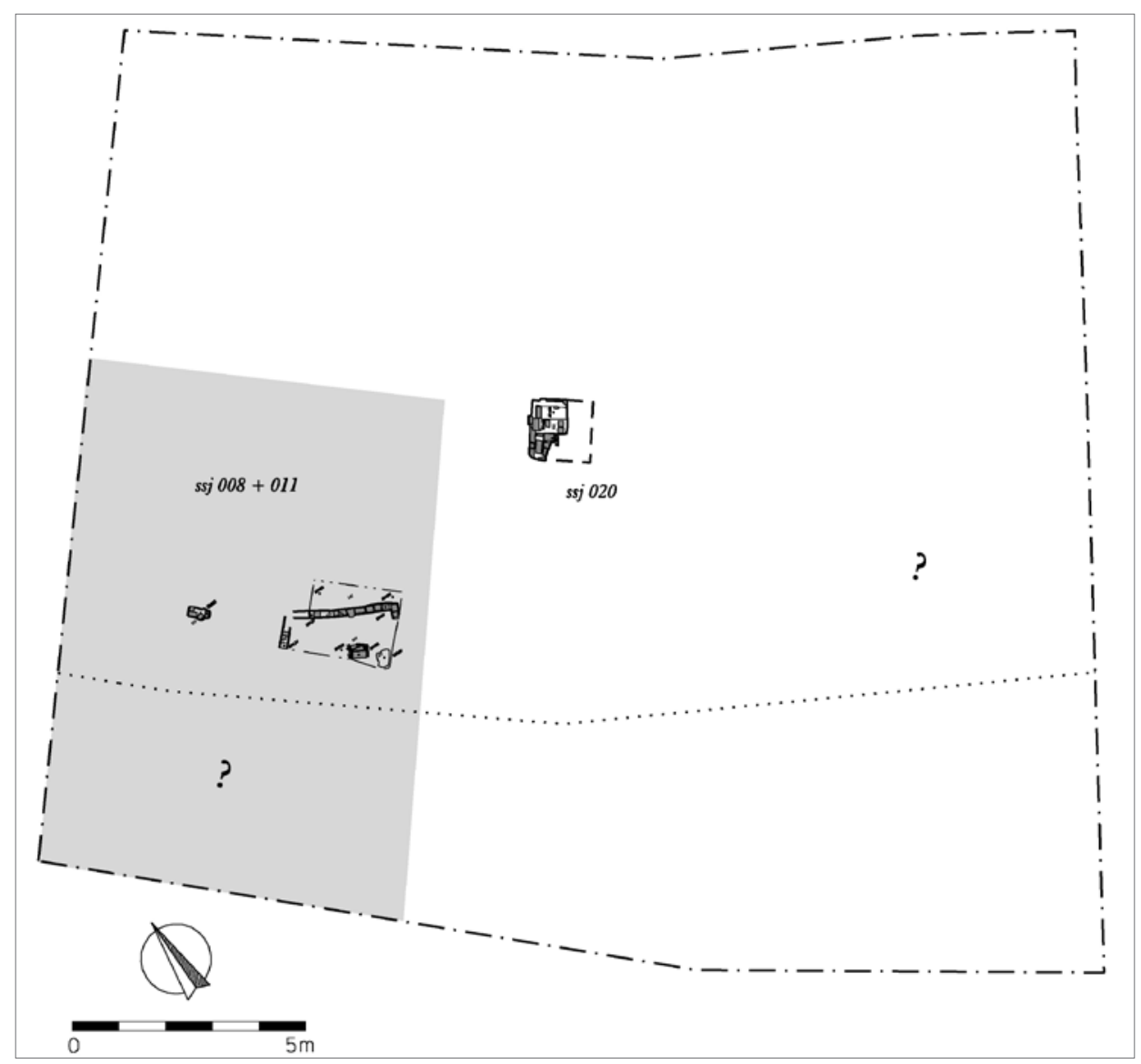

Obr. 9. Starší dřevohliněná zástavba parcely, zřejmě 2. polovina 17. století. Je zobrazena stavba s. s. j. $008+012$, která měla svého předchůdce s. s. j. 010 + 011, otopné zařízení s. s. j. 020 může být starší.

Abb. 9. Ältere Holz-Lehm-Bebauung der Parzelle, offenbar 2. Hälfte 17. Jahrhundert. Dargestellt wird der Bau Bündel stratigraphischer Einheiten 008 + 012, dessen Vorgänger Bündel stratigraphischer Einheiten 010 + 011 war, Heizvorrichtung Bündel stratigraphischer Einheiten 020 kann älter sein. 
(ca $2 \mathrm{~m}$ ). Pokud by s některým z nich souviselo, bylo by zřejmě vysunuto mimo jeho půdorys a ukryto maximálně v jeho přístavku (snad lehčí konstrukce).

V dalším období, kdy jsou relikty zástavby reprezentovány takřka výhradně zděnými konstrukcemi, byla př́tomnost staveb zaznamenána v západní i východní části parcely. Nástupcem domu s. s. j. $008+012$ se stal dům s. s. j. 013 až 016, opět štítově orientovaný k uliční čáře. Stejně orientována byla stavba při východní hranici parcely (s. s. j. 023). Později byla př́estavěna a podél uliční linie rozšířena (s. s. j. 024) směrem k domu s. s. j. 013 až 016. Mezi budovami zůstal zachován průjezd. Lze uvažovat, že ve starším období k propojení staveb nedošlo. Tak je zachycena situace např́klad na plánu z roku 1788 (Archiv města Brna, Aa2). Plány z let 1749 (Österreichisches Staatsarchiv - Kriegsarchiv, Inland C IV a) Brünn Nr. 14, 1749) a 1754 (v kopii $\mathrm{z}$ roku 1815, Archiv města Brna, fond U 9, sign. K11) zobrazují dvě budovy, mezi něž je vložen menší objekt (nedosahuje šířky př́ístavby s. s. j. 024). Na druhém z plánů je proveden na rozdíl od zděných (červených) staveb šedou barvou. Snad se jednalo o dřevěnou konstrukci. Je otázkou, zda by nemohlo jít pouze o „koridor“ komunikačně propojující obě budovy v úrovni prvního patra. O plochostropém průjezdu hovoří popis domu z roku 1820 (viz oddíl 2 Historie domu Kopečná 24). Od roku 1825 zobrazují plány již celistvou, spojenou zástavbu v podobě písmene U se souvislou čelní budovou a vybíhajícími dvorními křídly. V této době dosahuje zastavěná plocha výměry $325 \mathrm{~m}^{2}$. Budova při ulici má rozměry $22 \times 8,5 \mathrm{~m}$, dvorní křídla zasahují do vzdálenosti $19 \mathrm{~m}$ od uliční čáry, západní je široké $7,5 \mathrm{~m}$, východní $5 \mathrm{~m}$. V poslední třetině 19 . století bylo obestavění dvora dokončeno propojením dvorních křídel stavbou při zadní hranici parcely (viz např. indikační skica z roku 1876 - Moravský zemský archiv, fond D 9, sign. MOR059518760). Po této př́istavbě se $\mathrm{v}$ terénu nezachovaly v podstatě žádné stopy.

S vývojem zástavby úzce souvisí problematika rozsahu vlastního pozemku. Zde je nutné si připomenout text zprávy z roku 1710, podle které H. E. Kellner koupil „pusté místo o šírce 6 sáhư" (viz oddíl 2 Historie domu Kopečná 24). Dnes má parcela šířku dvojnásobnou $(21,5 \mathrm{~m})$. Z toho vyplývá, že se zpráva pozemku netýká, anebo že v nejstarším období šlo o dvě samostatné parcely a zpráva se vztahuje pouze $\mathrm{k}$ jedné $\mathrm{z}$ nich. Pokud by šlo o dvě parcely ještě v období existence stavby s. s. j. 023 (př́ípadně ještě s. s. j. 024), přimykaly by se k sobě průjezdovou (dvorní částí). Je však možné, že budova s. s. j. 023 byla již výsledkem nové výstavby po sloučení parcel do jednoho celku. Její menší šířka (5 m) než u domu s. s. j. 013 až 016 (7 m) by mohla naznačovat spíše její hospodářské využití. Je možné vznést hypotézu, že ,progresivnější“ byla západnější z parcel, jejíž majitel získal sousedův majetek. Nepřítomnost pozůstatků nejstarší zástavby ve východní části pozemku by se dala vysvětlit tím, že nový majitel ji bezezbytku odstranil a vybudoval $\mathrm{v}$ těchto místech hospodářské zázemí nové parcely. Využití př́íslušné zástavby k takové funkci potvrzuje zpráva z roku 1820. Anebo se nabízí varianta, že nepřítomnost reliktů nejstarších staveb ve východní části můžeme spojit s oním „pustým místem“, které koupil H. E. Kellner. On či jeho nástupci získali později také sousední parcelu. Je otázkou, zda stavba s. s. j. 023 byla jejich původním domem, či k její výstavbě došlo až po sloučení pozemků.

Dalším tématem týkajícím se rozsahu pozemku je jeho hloubka od uliční čáry. Zadní hranici vytvářela upravená stěna skalního srázu. Otázkou je, zda nedošlo k vylámání skály a posunu někdejší přirozené hrany. Nabízí se myšlenka, že v nejstarším období se mohla nacházet na úrovni zadní stěny domu s. s. j. 013 až 016, v průměru o 5,5 m blíže k ulici. Do jisté míry ji podporuje skutečnost, že v zadní části parcely nebyly zaznamenány žádné starší archeologické situace, včetně výkopů do skalního podloží, které byly jinde zaregistrovány. Posunem skalní stěny by vznikl prostor pro př́ístavbu s. s. j. 017 a s. s. j. 025 v prrípadě budovy s. s. j. 024. Archeologický výzkum nedokázal stanovit dobu vzniku zástavby v těchto místech. Nejpozději sem zasahovala v roce 1820 , kdy se dovídáme, že dům měl dvůr o „výměre 28 čtverečních sáhư“. Tento údaj se shoduje se skutečností, kterou potvrdil archeologický výzkum pro dobu existence staveb s. s. j. 013 až 017 a s. s. j. 024 a 025.

Důvodem k jednotlivým přestavbám budov byly zřejmě účelové potřeby jejich majitelů. Nebyly zaznamenány žádné výrazné doklady požáru, který by pozemek postihl a vynutil si tak 


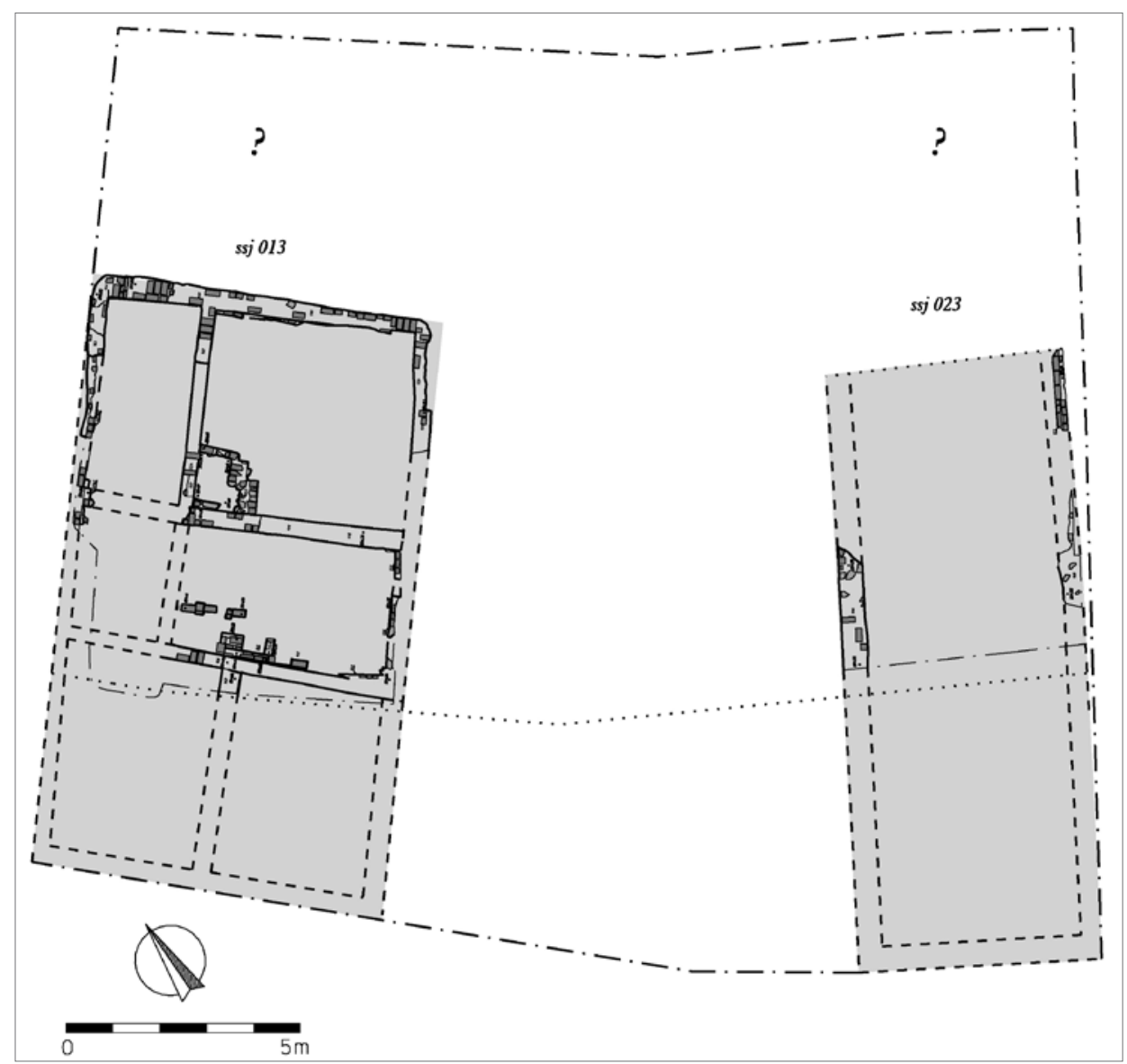

Obr. 10. Nejstarší zděná zástavba parcely, 18. století.

Abb. 10. Älteste Bebauung aus Stein der Parzelle, 18. Jahrhundert.

novou výstavbu. Zcela vyloučit tuto možnost ovšem nelze. Stopy požáru (zvláště u zděné zástavby) mohly být odstraněny a časem úplně setřeny.

Co se týče problematiky časového určení, tak nejstarší dokumentovanou fázi vývoje zástavby - dům s. s. j. $010+011$ a jeho nástupce s. s. j. $008+012-1$ ze zasadit pravděpodobně ještě do období 17. století, snad do jeho druhé poloviny. Blíže datovat jednotlivé stavební počiny u mladší zástavby není možné. Nejpozději v roce 1820 byly všechny stavby (s. s. j. 013 až 018 a 023 až 025) spojeny do jednoho komplexu, který půdorysem a stavební hmotou odpovídá příslušným archivním plánům a také fotografiím z roku 1961, pořízeným před asanací domu (Archiv města Brna, fond U 5, sign. XIIIa, č. 54). V poslední třetině 19. století byl doplněn výše zmíněnou stavbou při zadní hranici parcely, která se v archeologickém terénu neprojevila.

\section{Podoba zástavby}

Nejstarší dokumentovanou stavbu (s. s. j. 010 + 011) lze hodnotit výhradně z její planýrované destrukce. Jako stavební materiál dominovalo dřevo (konstrukční prvky) a hlína (v podobě mazanice jako doplňková hmota). Další informace terénní situace nepřinesla. Minimálně výrazným podílem byla dřevohliněná složka zastoupena také u následující stavby s. s. j. $008+012$. 


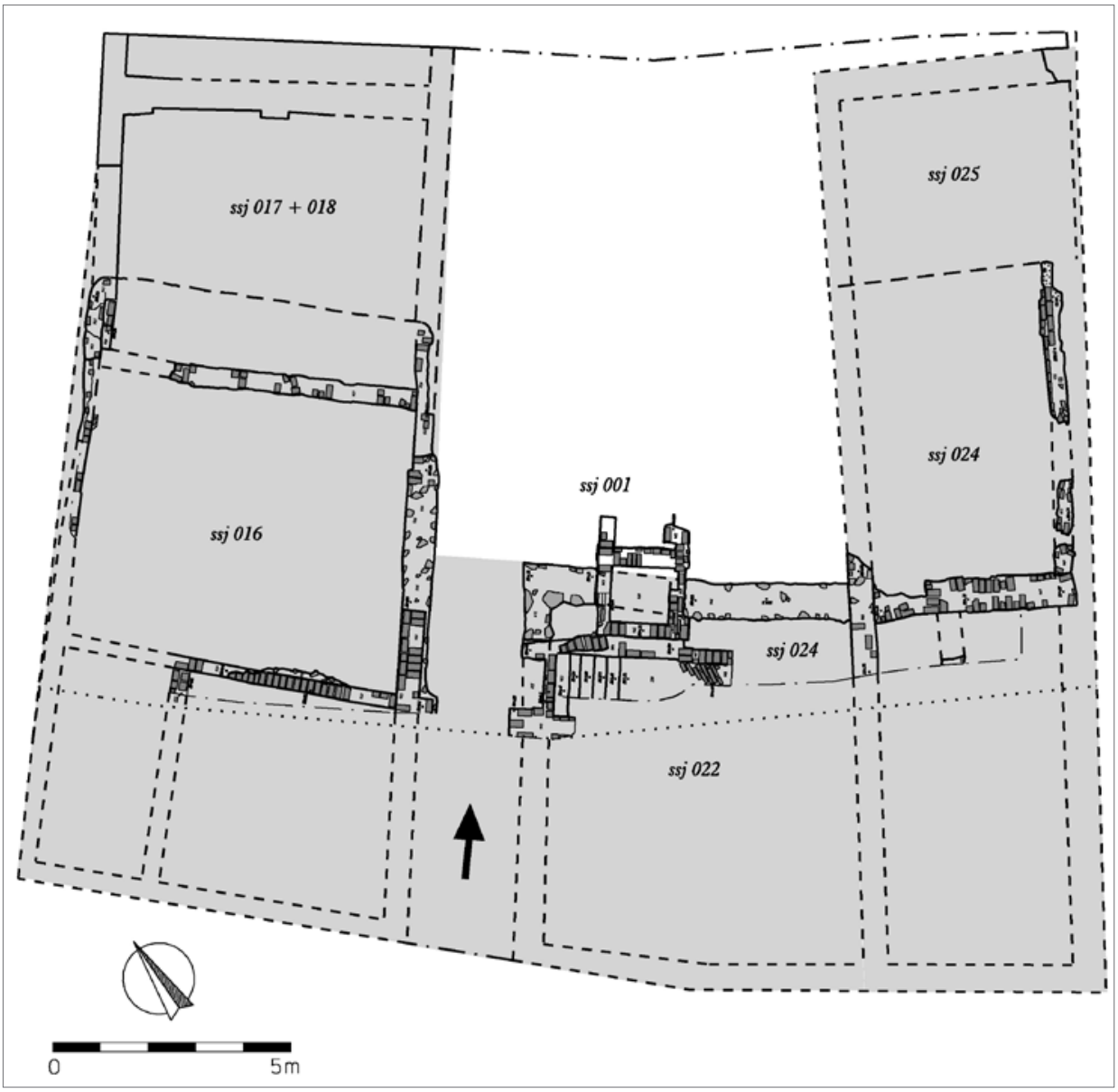

Obr. 11. Mladší zděná zástavba parcely, 18.-20. století.

Abb. 11. Jüngere Bebauung aus Stein der Parzelle, 18.-20. Jahrhundert.

Uplatnily se však i konstrukce pojené maltou. Z malty byly tvořeny omítky alespoň některých stěn. Doloženy byly úpravy vápennými líčkami. Názorným př́ikladem rozmanitého využití stavebních materiálů byl relikt konstrukce (př́íčky?) v interiéru stavby. Tvořily ho zlomky cihel tř́i původních formátů pojené místy maltou, místy hlínou. Maltou byl omítnut jeden z líců. $\mathrm{Na}$ omítce byl nanesen černý (druhotně?, očouzený?) vápenný nátěr, překrytý následně bílým nátěrem. Je možné, že subtilní zídka představovala konstrukci kolem otopného zařízení, které bylo umístěno na podlahové úrovni (s. s. j. 009). Zpočátku se jednalo asi jen o jednoduché ohniště. Došlo k vypálení hliněné podlahy. Následovala vrstva popela, poté bylo otopné zařízení (nebo jeho základ) vybudováno $\mathrm{z}$ cihel pojených hlínou. $\mathrm{K}$ jeho podobě, ani přesné funkci se nelze vyjádřit, protože bylo v mladším období zničeno. Šlo spíše o drobnější záležitost. Podlaha při něm byla zpevněna kamennou dlažbou. Okolní podlaha byla hliněná, utvářel ji v podstatě povrch planýrky někdejší stavby s. s. j. $010+011$. Byla na něm usazena tenká nášlapová vrstvička. V jiné části domu se podařilo zachytit segment podlahy z cihel pojených šedou maltou. Popsané stavby nebyly podsklepeny. Pokud ano, mohlo tomu tak být pouze v čelní (nezkoumané) partii. 
Relikty mladších staveb, které dokumentoval archeologický výzkum, byly reprezentovány výhradně zděnými konstrukcemi. V drtivé většině ovšem byla zachována jenom úroveň základových a náběhy nadzemních zdiv. Konstrukční prvky tvořily kameny a pálené cihly. Kámen (většinou místní provenience) se uplatňoval takřka výhradně u základových zdí. U dvou příček stavby s. s. j. 013 byly zaregistrovány nepálené cihly. Jako pojivo se uplatňovala malta, v př́ipadě několika konstrukcí stavby s. s. j. 013 byla užita hlína. Standardem již byly zřejmě omítky a ošetření vápennými ličkami. Přítomnost dřevěných a dřevohliněných konstrukcí se v dokumentovaných situacích výrazným způsobem neprojevila. Je však doložena písemnými prameny, ze kterých se dovídáme, že ještě v roce 1860 stávala ve dvoře dřevěná patrová kolna na zděných pilíríích. Podle písemných pramenů byl dům nejméně od roku 1820 patrový a byl vybaven střechou z pálené krytiny (viz oddíl 2 Historie domu Kopečná 24). K těmto otázkám nepřinesl archeologický výzkum v podstatě žádné informace. Podsklepení (a to dodatečné) bylo zaznamenáno pouze u části stavby s. s. j. 024. Sklep byl př́stupný z průjezdu. Pravděpodobně jde o sklep jediný a poměrně mladý. Lze tak usuzovat nejen na podkladě archeologicky získaných poznatků, ale také z toho, že popisy domu z konce 18. a z 19. století o sklepech nehovoří.

K vybavení staveb nepřinesla terénní situace mnoho poznatků. Ve východní části parcely se $\mathrm{z}$ nich dochovaly jenom segmenty obvodových zdiv. V západní části se $\mathrm{v}$ jihozápadním rohu zadní místnosti stavby s. s. j. 013 podařilo dokumentovat snad základ pro usazení otopného zařízení. S jistou mírou opatrnosti by bylo možné dát do souvislosti s vytápěním rovněž subtilní cihlové konstrukce při jihozápadní stěně sousední místnosti blíže ulice. Zadní místnost byla $\mathrm{v}$ době existence stavby (fáze) s. s. j. 014 vybavena podlahou z cihel pojených maltou, ve stejné době sloužila v sousední místnosti blíže $\mathrm{k}$ ulici jen podlaha hliněná. V tomto ohledu je zajímavá dispoziční kontinuita se starší stavbou s. s. j. $008+012$, u níž byla cihelná podlaha zachycena ve stejném prostoru. Obdobě je tomu u otopného zařízení s. s. j. 009 a jmenovaných subtilních konstrukcí v rámci stavby s. s. j. 013. Příslušné místnosti tedy sloužily stejným či podobným účelům.

Na otázky, zda a kdy mohly být některé části staveb vytápěny prostřednictvím kachlových kamen, nepřinesl archeologický výzkum jednoznačné odpovědi. Nepodařilo se v tomto směru dokumentovat žádnou výraznější aktivitu. Bylo sice získáno na 180 zlomků komorových kachlů, jednalo se ale většinou o jednotlivé kusy či malé kolekce z celkem 35 uloženin. Největší soubor (35 fragmentů) poskytla výplň jámy na hašení vápna s. s. j. 002, která předcházela vybudování stavby s. s. j. 024. Řada zlomků byla součástí zásypů nejstarších výkopových aktivit. Šest fragmentů obsahovala destrukční planýrka domu s. s. j. 008.

V otázce vybavení staveb se můžeme více opřít o výpověd’ archivních pramenů. Jen zřídka sice popisují konkrétní jednotlivosti, ovšem z funkčního určení jednotlivých partií si lze jistou představu vytvořit. Použitelný je především popis domu z roku 1820 (viz oddíl 2 Historie domu Kopečná 24). Část stavby s. s. j. 024 při uliční čáře můžeme ztotožnit s ,prostornou vozovou kolnou“, v partii směřující do dvora byla umístěna „klenutá stáj pro pět koni“. V prostoru stavby s. s. j. 025 se nacházela „stáj pro dva koně a nad ní sýpka s cihelnou dlažbou“. Popis domu v západní části parcely koresponduje s fází s. s. j. 015. „Dva vytápěné pokoje“ při ulici zůstaly z velké části ukryty pod nezkoumanou plochou. Do dalších prostor stavby je možné umístit „předsiň s klenutou kuchyni" za jmenovanými pokoji. „Vedle předsině byla dalši vytápěná mistnost s prilehlou kuchyní. Následovala predsín se schodištěm do patra." Do přístavby s. s. j. 017 lze potom situovat „vytápěný klenutý pokoj a za ním klenutou kuchyni, které se mély nacházet na konci budovy".

Konečný výsledek stavebního vývoje domu ukazují jeho fotografie z roku 1961 (Archiv města Brna, fond U 5, sign. XIIIa, č. 54). Zachycují patrovou stavbu se střechami pokrytými pálenou krytinou. Průčelí je vybaveno omítnutou fasádou. V patře ji prolamuje devět oken, $v$ přízemí dvoje vstupní dveře, hlavní průjezd a šest oken. Neomítnutý líc západní stěny domu tvoří cihelné zdivo. Přimykal se k ní sousední dům (proto absence omítky). Ven směřují dvě menší okna a jeden větrací otvor (?) v zadní části dvorního křídla. Patrné jsou dva komíny. 


\section{Nakládání s odpadem}

Otázku, jakým způsobem obyvatelé parcely nakládali s vyprodukovaným odpadem, se při archeologickém výzkumu nepodařilo zodpovědět. Obvyklé „klasické“ odpadní jímky použity nebyly. Pravděpodobně tomu tak bylo proto, že by bývalo bylo nutné je vylámat do skalního podloží. Není ovšem vyloučeno, že jako odpadní jímka sloužil objekt s. s. j. 001 (viz oddíl 4 Nálezová situace). Odpad byl určitě vyvážen, možná mohl být ukládán i v nedalekém okolí. Na parcele je však nutné předpokládat př́tomnost objektu, $v$ němž by docházelo $k$ jeho dočasnému deponování. Fungovat musel také záchod. Zřejmě šlo o nadzemní záchod (zděné či dřevěné konstrukce), jehož stopy se v terénní situaci nezachovaly.

\section{Zdroj vody}

Vlastní zdroj vody nebyl na parcele doložen. Nezmiňují ho ani písemné prameny. Smysluplné hloubení studny znemožnilo skalní podloží. Není vyloučeno, že jako cisterna na vodu sloužil objekt s. s. j. 001 (viz oddíl 4 Nálezová situace). Obyvatelé domu mohli jako zdroje využívat blízké vodoteče - Svratecký náhon a potůček ze studánky pod Petrovem. Otázkou je přítomnost veřejné studny. Existenci jedné z nich i pro mladší období dokládá fotografie z roku 1907 při domě Kopečná 274/36 (Archiv města Brna, fond U 5, sign. XIIIa, č. 8). Její vzdálenost od parcely Kopečná 24 činila přibližně $60 \mathrm{~m}$.

V této souvislosti je zajímavá problematika odvodu deštové vody, která se nemohla na skalním podkladu vsakovat. Podloží bylo zřejmě upraveno (spádováno) tak, aby voda vytékala prostorem průjezdu ven na ulici. Relikty jiných opatření nebyly při výzkumu registrovány. Až v nejmladším období situaci vyřešilo zahloubené betonové potrubí, procházející úhlopříčně prostorem dvora skrze průjezd na ulici. Do něho byla svedena také odpadová roura ze západní části domu.

\section{Obyvatelé parcely}

$\mathrm{Na}$ základě získaných archeologických pramenů se toho o životě obyvatel parcely mnoho konkrétního říci nedá. Způsob jejich obživy se do archeologické situace nepromítl takovým způsobem, abychom ho byli schopni rozeznat. Zaměstnání majitelů domu známe až pro mladší období jeho existence, v závěru 18. a v 19. století, díky výpovědi písemných pramenů. První z nich byl řezník, následovaly profese, které měly blízko ke koním - kočí, podkoní a opět kočí. Ve druhé polovině 19. století hospodařil v domě stolař (viz oddíl 2 Historie domu Kopečná 24). Zlomky tř́i dýmek snad svědčí o zálibě některých z obyvatel v kouření tabáku. Za doklad minimálně „běžné“ zbožnosti může být považován nález benediktinské svátostky.

\section{Závěr}

Archeologický výzkum parcely domu Kopečná 24 přinesl ve svých výsledcích důležité poznatky k poznání její historie. To, že potvrdil přítomnost četných archeologických situací, bylo jasnou odpovědí na skeptické hlasy, a to i z řad odborné veřejnosti, které jejich existenci vylučovaly s odůvodněním, že na lokalitě „,není nic, jen skála“. Získané poznatky po konfrontaci s archivními prameny umožnily do jisté míry rekonstruovat vývoj a podobu zástavby parcely od jejího vzniku až po demolici v 60 . letech 20. století. Počátky osídlení pozemku lze klást do 17. století, minimálně do jeho druhé poloviny. V nejstarším období se pravděpodobně jednalo o dvě parcely, teprve později sloučené do jednoho majetku. První stavby byly dřevohliněné, následně byla zástavba tvořena ve většinové části zděnými konstrukcemi. Lze hovořit o cihlové architektuře. Závěrečným výsledkem vývoje byl poměrně velký, patrový dům s jednotlivými dvorními křídly, která vymezovala centrální prostor dvora.

Dosažené vyhodnocení je př́kladem vývoje novověké zástavby na pozemku, který byl součástí sídelní struktury předměstí. Do budoucna umožňuje srovnání s obdobnými lokalitami či s vybranými parcelami městskými. Z brněnských předměstí byl doposud stejným způsobem vyhodnocen pouze vývoj parcely č. 1149/3 - Kopečná 40 (Zůbek 2016). Je tedy umožněna kom- 


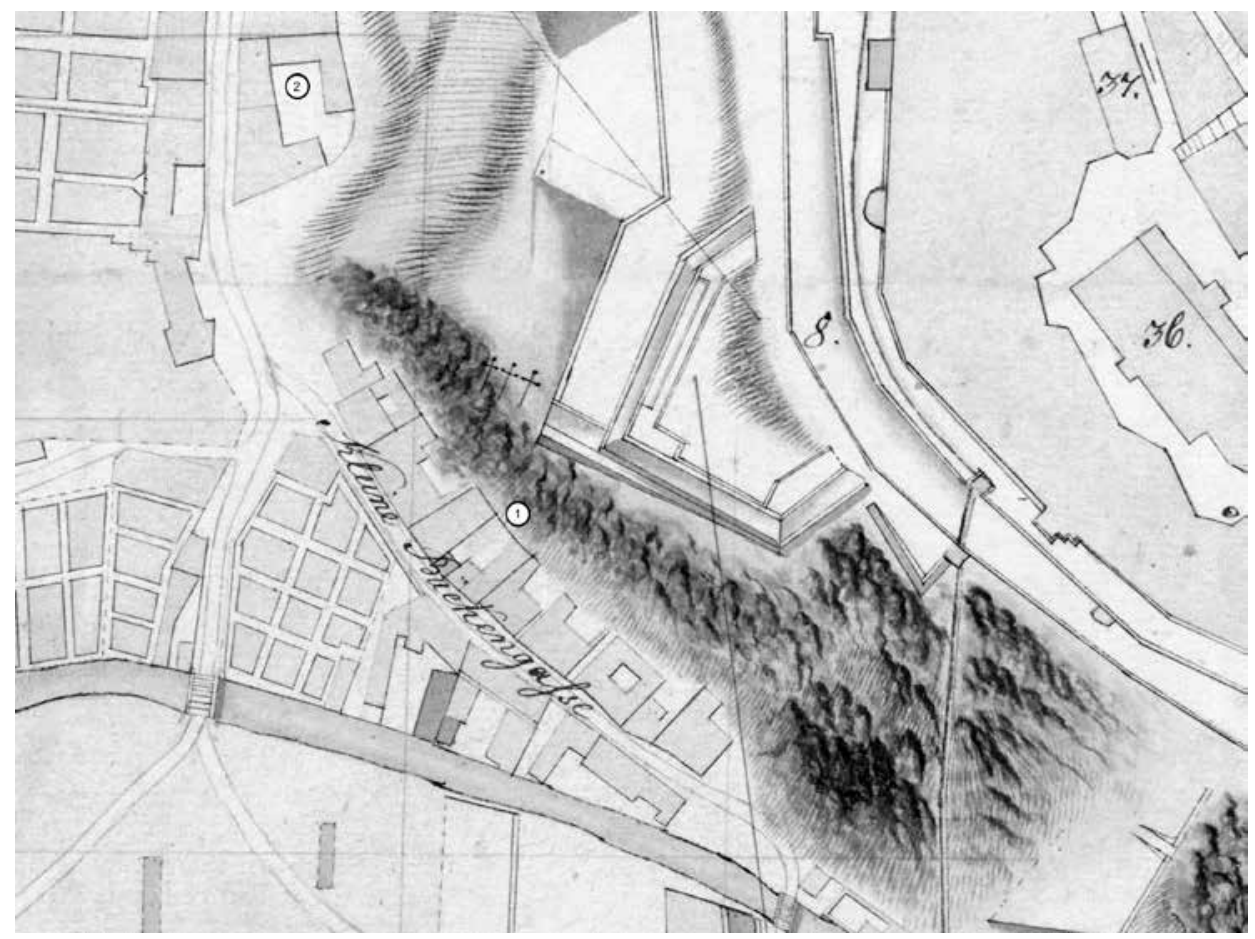

Obr. 12. Výřez plánu z roku 1754 v kopii z roku 1815, Archiv města Brna, fond U 9, sign. K11. Č́́sla v bílých kroužcích označují: 1 - dům Kopečná č. 24, 2 - dům Kopečná č. 40.

Abb. 12. Ausschnitt aus einer Planskizze aus dem Jahr 1754 in einer Kopie aus dem Jahr 1815, Archiv der Stadt Brno, Bestand U 9, Sign. K11. Die Nummern in den weißen Kreisen kennzeichnen: 1 - Haus Kopečná-Str. Nr. 24, 2 - Haus Kopečná-Str. 40.

parace dvou sídelních jednotek reprezentujících zástavbu podél starobylé komunikace. Rozdílový faktor je v tom, že parcela č. 1149/3 byla součástí starého osídlení, k jejímu zastavění došlo nejpozději ve 13. století. V této skutečnosti se do velké míry odráží zřejmě její příznivější poloha. I když jsou zkoumané parcely od sebe vzdáleny pouhých $100 \mathrm{~m}$, mohly být podmínky pro sídelní využití výrazně odlišné. Významným prvkem byla určitě vzdálenost od Svrateckého náhonu a přilehlého podmáčeného terénu (viz oddíl 1 Historický úvod). Terénní konfigurace je obdobná, oba pozemky se směrem od ulice zařezávají do svažitého terénu. Svah u parcely č. 1149/3 je mírnější, v prrípadě Kopečné 24 lze hovořit spíše o srázu. Dalším rozdílovým faktorem je skladba podloží. Kopečná 24 byla založena na skále, ve druhém případě se jedná víceméně o „sprašovou lokalitu“. Podloží je bezpochyby výrazným prvkem, který ovlivňuje podmínky života na př́slušném místě, poskytuje mu možnosti a staví limity. Jako př́íklad může posloužit dřevohliněná zástavba, zaznamenaná na obou pozemcích. Hliněná složka mohla být v případě parcely č. 1149/3 zajištěna (nebo alespoň zčásti) z vlastních zdrojůn, na parcelu Kopečná 24 musela být dopravena (a zakoupena).

Skalní podloží má nepochybnou výhodu ve své statické únosnosti a stabilitě. V případě zahloubených aktivit není nutné jejich stěny zajištovat výdřevou. Jejich hloubení ale vyžaduje nesrovnatelně větší úsilí než u výkopů do sprašové hlíny. V tomto ohledu pozorujeme výrazný nepoměr mezi četnými výkopovými aktivitami na parcele č. 1149/3 a spíše ojedinělými př́ipady na parcele domu Kopečná 24 . Důvodem není rozhodně větší rozsah zkoumané plochy. Většina výkopových aktivit na parcele č. 1149/3 pochází ovšem z období středověku. Představovaly je 


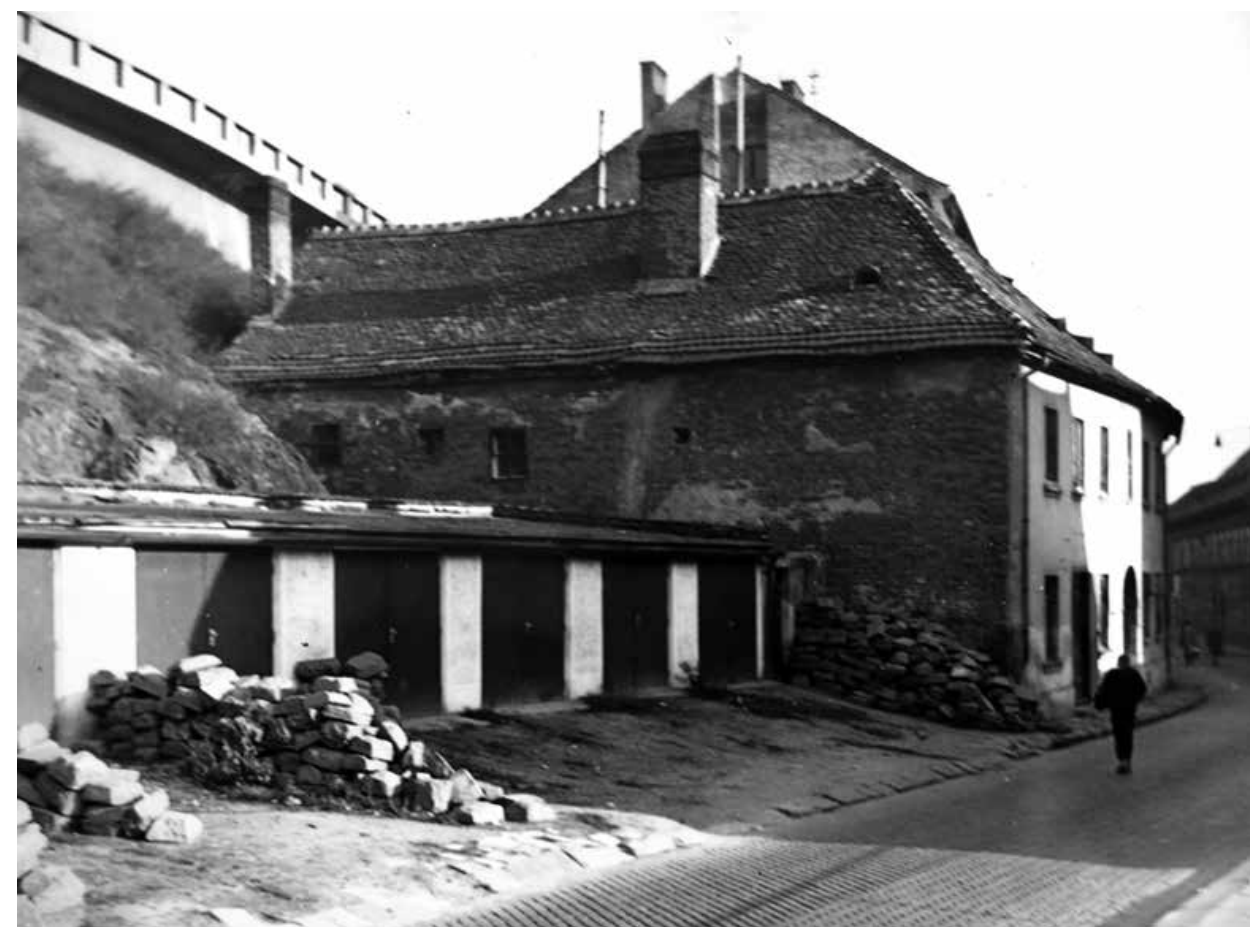

Obr. 13. Pohled od severozápadu na dům Kopečná č. 24 v roce 1961, Archiv města Brna, fond U 5, sign. XIIIa, č. 54. Abb. 13. Blick aus Nordwesten auf das Haus Kopečná-Str. Nr. 24 im Jahr 1961, Archiv der Stadt Brno, Bestand U 5, Sign. XIIIa, Nr. 54.

často zahloubené partie staveb, různé typy sklípků a lochy. Zdá se však, že v období novověku májí projevy zástavby na obou parcelách podobný charakter. Zahloubené části staveb chybí. Je tedy nutné do úvah zapojit nejen výhody a nevýhody životního prostřední, ale také možné a nutné potřeby obyvatel. Ty se mohly aktuálně měnit v souvislosti s vývojem společnosti, změnou obživy apod. Příhodnějším geologickým podmínkám lze však jistě přisuzovat výrazný podíl na př́ítomnosti odpadních jímek na parcele č. 1149/3, které zde ve starším středověkém období chyběly. V 18.-19. století byla na parcele vyhloubena také studna. Tyto prvky u Kopečné 24 postrádáme, ač se lze domnívat, že potřeby obyvatel obou parcel byly v těchto ohledech obdobné.

Jednoznačné závěry a přesná srovnání obou parcel nelze v úplnosti provádět. Pro středověk je důvodem absence osídlení na pozemku domu Kopečná 24, na druhé straně míra dochovanosti reliktů novověké zástavby parcely č. 1149/3 (především jednotlivých staveb) byla spíše nevýrazná. Poznatky získané přri výzkumu a z nich odvozené závěry budou muset být testovány porovnáváním s výsledky vyhodnocení vývoje dalších parcel. Viděno optikou místních poměrů při Kopečné ulici, je nutné očekávat plnohodnotné zpracování výsledků starších výzkumů. Přínosné informace mohou vzejít z komparace se zástavbou Provaznického vršku (akce č. A43/2004 Kopečná 43, A12/2008 - Kopečná 41, předběžně Holub a kol. 2006, 207-208; Holub a kol. 2009, 364-366). Dủležitá bude konfrontace projevů zástavby na parcelách, které nebyly jako pozemky Kopečná 24 a 40 zaříznuty do svažitého terénu, ale naopak byly vytyčeny od komunikace po svahu směrem dolů (akce č. A55/2006 - Kopečná 37, A7/2012 - Kopečná 33, předběžně Holub a kol. 2008, 379-380; Černá a kol. 2013, 167-168). Velice zajímavé by mohly být výsledky výzkumů parcel při jižní linii ulice v jejím jihovýchodním úseku (akce č. A5/2009 - Kopečná 15, A15/2015 - Kopečná 17). Nacházely se již v těsné blízkosti Svrateckého náhonu a jejich zástavba 
se musela vyrovnávat s podmínkami zamokřeného terénu. Kromě dosavadních archeologických akcí lze očekávat nové poznatky, které budou získány při dalších výzkumech, jež se v blízké budoucnosti uskuteční v souvislosti s plánovanými stavebními počiny $\mathrm{v}$ tomto prostoru.

Kopečná ulice na své délce přribližně $0,5 \mathrm{~km}$ sestupuje od Provaznického vršku do inundace někdejšího Svrateckého náhonu a překonává tak převýšení $17 \mathrm{~m}$. Přestože se v globálnějším pohledu jedná o malé území, prochází ulice v rámci místních poměrů dílčími lokalitami s rozličnými geomorfologickými a př́rodními podmínkami, které se mohly promítat do „způsobu“ osídlení a ovlivňovat jeho projevy. Jejich studium a vzájemné srovnání může obohatit naše poznání nejen v hranicích brněnského prostoru, ale rovněž širšího kontextu problematiky středověkého a novověkého osídlení.

Vedle ostatních archeologických počinů se stal archeologický výzkum parcely domu Kopečná 24 dalším základním kamenem řady, která vede k objasnění topografického vývoje této části města. Potvrdil, že zástavba jihovýchodní části Kopečné ulice vznikala až v období novověku. Na základě získaných informací lze uvažovat o druhé polovině 17. století. Náznaky, že by zde jistá zástavba mohla existovat již před třicetiletou válkou, budou muset podepř́ít výsledky dalších výzkumů. Budoucí výzkumy by si rovněž měly dát za cíl prokázat úplnou absenci případného středověkého osídlení, nebo popsat případné využívání prostoru k jiným aktivitám v tomto období.

Svým dílem přispěl předmětný výzkum k řešení problematiky předměstské zástavby Brna. Její struktura a urbanistická kompozice se od druhé poloviny 17. století zásadně změnila. Podílely se na tom předcházející válečné události, ale především výstavba bastionového opevnění, kterým bylo město nově obkrouženo. Některé části předměstského osídlení zanikly definitivně, struktura jiných se výrazně změnila, některá území byla nově osazována, docházelo zřejmě k majetkovým posunům. Průběh tohoto procesu a jeho průvodní jevy nebyly dosud jako samostatné téma náležitě vyhodnoceny. Studium osídlení vázaného na Kopečnou ulici, s jeho starobylou i novou částí, může k pochopení a řešení problematiky přispět výraznou měrou.

\section{Prameny a literatura}

Archiv města Brna, fond A 1/3, rkp. č. 147, fol. 10. Archiv města Brna, fond A 1/3, rkp. č. 1914, fol. 76 . Archiv města Brna, fond A 1/3, rkp. č. 1915, fol. 2.

Archiv města Brna, fond A 1/3, rkp. č. 1915, fol. 70.

Archiv města Brna, fond A 1/3, rkp. č. 1917, fol. 160.

Archiv města Brna, fond A 1/3, rkp. č. 1918, fol. 310.

Archiv města Brna, fond A 1/3, rkp. č. 1919, fol. 66.

Archiv města Brna, fond A 1/3, rkp. č. 1919, fol. 100.

Archiv města Brna, fond A 1/3, rkp. č. 1919, fol. 169.

Archiv města Brna, fond A 1/33, inv. č. 718, kart. 175.

Archiv města Brna, fond U 5, sign. XIIIa, č. 8.

Archiv města Brna, fond U 5, sign. XIIIa, č. 54.

Archiv města Brna, Plan Die Esplanade der Festung Brünn... 1788, Aa2.

Archiv města Brna, Plan von Brünn, 1754 (kopie 1815), fond U 9, sign. K11.

Archiv města Brna, Situationsplan der könig. Landeshaupstadt Brünn... 1868, fond U 9, sign. K37a.

BORSKÝ, P., 2015: Exkurs: Historie domu Kopečná 24. In: Černá, L.-Zůbek, A., Nálezová zpráva o provedení záchranného archeologického výzkumu při stavbě „Parkovací dům Kopečná“. Nálezová zpráva č. 6/13 ulož. v archivu společnosti Archaia Brno, o.p.s.

BURIAN, V., 1969: Doba úpadku a zárodky nových výrobních vztahů (1618-1765). In: Dějiny města Brna 1. (Dřímal, J.-Peša, V., red.), 149-179. Brno.

ČERNÁ a kol., 2013: Černá, L.-Dejmal, M.-Holub, P.-Kolařík, V.-Merta, D.-Peška, M.-Sedláčková, L.Zbranek, H.-Zůbek, A., Brno (okr. Brno-město), PV 54, č. 2, 148-184.

ČERNÁ, L.-ZŮBEK, A., 2015: Nálezová zpráva o provedení záchranného archeologického výzkumu při stavbě „Parkovací dům Kopečná“. Nálezová zpráva č. 6/13 ulož. v archivu společnosti Archaia Brno, o.p.s. 
DŘÍMAL, J., 1973: Z dějin brněnských předměstí. In: Dějiny města Brna 2 (Dřímal, J.-Peša, V., red.), 255-319. Brno.

FLODROVÁ, M., 1997: Brněnské ulice a vývoj jejich názvů od 13. století po dnešek. Brno.

FLODROVÁ, M.-MÜLLER, Z., 2007: Staré Brno. Vyprávění o minulosti nejstarší části města Brna. Brno.

HOLUB, P. a kol., 2005: Holub, P.-Kolař́k, V.-Merta, D.-Peška, M.-Zapletalová, D.-Zůbek, A., Předběžné výsledky záchranných archeologických výzkumů v Brně v roce 2004, PV 46, 111-169.

- 2006: Holub, P.-Kolařík, V.-Merta, D.-Peška, M.-Polánka, P.-Sedláčková, L.-Zapletalová, D.-Zůbek, A., Brno (okr. Brno-město), PV 47, 170-226.

- 2008: Holub, P.-Kolařík, V.-Merta, D.-Peška, M.-Polánka, P.-Sedláčková, L.-Zapletalová, D.-Zůbek, A., Brno (okr. Brno-město), PV 49, 356-393.

- 2009: Holub, P.-Kolařík, V.-Merta, D.-Peška, M.-Polánka, P.-Sedláčková, L.-Zapletalová, D.-Zůbek, A., Brno (okr. Brno-město), PV 50, 345-376.

KUČA, K., 2000: Brno. Vývoj města, předměstí a připojených vesnic. Praha - Brno.

LECHNER, G. M., 1980: Der heilige Benedikt und die Volkskunde. In: 1500 Jahre St. Benedikt, Patron Europas (Neuhardt, J., ed.), 46-53. Salzburg.

MERIAN, M. 1650: Topographia Bohemiae, Moraviae et Silesiae, das ist, Beschreibung und eigentliche Abbildung der Vornehmsten und bekandtesten Stätte und Plätze in dem Königreich Boheim und einverleibten Ländern, Mähren und Schlesien“. Frankfurt. Použitý exemplář je uložen v Moravské zemské knihovně v Brně pod signaturou ST3-0035.392.

Moravský zemský archiv, Indikační skica Bäckengasse grosse und kleine 1876, fond D 9, sign. MOR059518760.

Österreichisches Staatsarchiv - Kriegsarchiv, Inland C IV a) Brünn Nr. 11, 1699.

Österreichisches Staatsarchiv - Kriegsarchiv, Inland C IV a) Brünn Nr. 12, 1729.

Österreichisches Staatsarchiv - Kriegsarchiv, Inland C IV a) Brünn Nr. 14, 1749.

PROCHÁZKA, R.-WIHODA, M.-ZAPLETALOVÁ, D., 2011: V raném středověku. In: Dějiny Brna 1. Od pravěku k ranému středověku (Procházka, R., red.), 447-560. Brno.

PROCHÁZKA, R.-KOLAŘÍK, V.-ZŮBEK, A., 2013: Předměstí. In: Dějiny Brna 2. Středověké město (Jan, L., red.), 568-600. Brno.

RELATIONE: Relatione dell assedio di Bruna e de la fortezza di Spilberg. Vienna 1672. Použitý exemplář je uložen v Moravské zemské knihovně v Brně pod signaturou ST2-0018.958.

SMÍŠEK, K., 2014: Numismatické určení souboru mincí z archeologického výzkumu společnosti Archaia o.p.s. na lokalitě Brno, Kopečná-parkovací dům (A 053/2012). Velké Přílepy, rkp. ulož. v archivu společnosti Archaia Brno, o.p.s.

VIČAR, O., 1966: Místopis Brna ve 14. století (Předměstí), BMD 8, 226-273.

ZAPLETALOVÁ a kol., 2005: Zapletalová, D.-Čulíková, V.-Jankovská, V.-Lisá, L.-Rybníček, M., Př́íspěvek př́rodních věd a archeologie $\mathrm{k}$ historické topografii Starého Brno, Ve službách archeologie 6, $267-274$.

ZŮBEK, A., 2016: Vývoj historické zástavby parcely č. 1149/3 při Kopečné ulici v Brně - Die historische Entwicklung der Bebauung von Parzelle Nr. 1149/3 an der Brünner Straße Kopečná, AH 41, 345-362.

\section{Zusammenfassung}

\section{Die Entwicklung der historischen Bebauung auf der Parzelle des ehemaligen Hauses Nr. 24} in der Straße Kopečná in Brno

Das Gebiet um die Straße Kopečná befindet sich in direkter Nachbarschaft der mittelalterlichen Stadt. Es war von Anfang an in die Siedlungsstruktur seiner Vorstadt eingebunden. Im Mittelalter wurde vor allem der Bereich um den nordwestlichen Abschnitt der heutigen Straße besiedelt. Der südöstliche Abschnitt war wegen den natürlichen Verhältnissen offensichtlich nicht attraktiv, eine Bebauung ist dort erst für die Neuzeit belegt. Das ehemalige Haus in der Kopečná-Straße Nr. 24 war ein Bestandteil dieses Abschnittes und bildete an der nördlichen Linie des Verkehrsweges einen Teil der Straßenfront. Das Haus wurde Anfang der sechziger Jahre des 20. Jahrhunderts abgerissen.

Die archäologischen Erkenntnisse über die Entwicklung der Parzelle des Hauses in der Kopečná-Straße 24 wurden bei einer im Jahr 2012 durchgeführten archäologischen Rettungs- 
grabung gewonnen. Untersucht wurden $72 \%$ des gesamten Ausmaßes des ursprünglichen Grundstücks, das auf $420 \mathrm{~m}^{2}$ (ca. 21,5 $\times 19 \mathrm{~m}$ ) beziffert werden kann. Die Grabungsergebnisse machten es nach einem Abgleich mit den Archivquellen bis zu einem bestimmten Grade möglich, die Entwickung und die Bebauungsform der Parzelle ab ihrer Entstehung bis zum Abriss in den sechziger Jahren des 20. Jahrhunderts zu rekonstruieren. Die Anfänge der Besiedelung des Grundstücks kann in das 17. Jahrhundert gelegt werden, und zwar mindestens in seine erste Hälfte. Im ältesten Zeitraum handelte es sich wahrscheinlich um zwei Parzellen, die erst später zu einem einzigen Besitz zusammengefügt wurden. Die ersten Bauten waren aus Holz und Lehm, anschließend bestand die Bebauung größtenteils aus Steinkonstruktionen. Man kann von einer Ziegelsteinarchitektur sprechen. Das abschließende Ergebnis der Entwicklung war ein relativ großes, einstöckiges Haus mit einzelnen Hofflügeln, welche den zentralen Hofraum umgrenzten.

Mgr. Antonín Zůbek, Ph.D., Archaia Brno, o.p. s., Bezručova 15, 60200 Brno, Česká republika, azubek@archaiabrno.cz 
